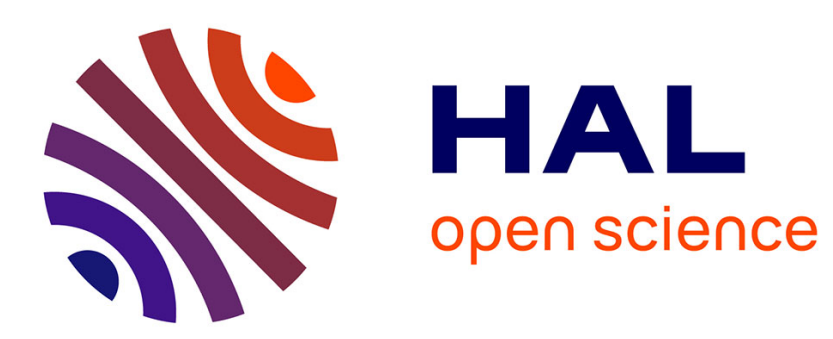

\title{
Beyond the water column: aquatic hyphomycetes outside their preferred habitat
}

Eri Chauvet, Julien Cornut, Kandikere R. Sridhar, Marc-André Selosse, Felix Bärlocher

\section{- To cite this version:}

Eri Chauvet, Julien Cornut, Kandikere R. Sridhar, Marc-André Selosse, Felix Bärlocher. Beyond the water column: aquatic hyphomycetes outside their preferred habitat. Fungal Ecology, 2016, vol. 19, pp. 112-127. 10.1016/j.funeco.2015.05.014 . hal-01237063

\section{HAL Id: hal-01237063 https://hal.science/hal-01237063}

Submitted on 2 Dec 2015

HAL is a multi-disciplinary open access archive for the deposit and dissemination of scientific research documents, whether they are published or not. The documents may come from teaching and research institutions in France or abroad, or from public or private research centers.
L'archive ouverte pluridisciplinaire HAL, est destinée au dépôt et à la diffusion de documents scientifiques de niveau recherche, publiés ou non, émanant des établissements d'enseignement et de recherche français ou étrangers, des laboratoires publics ou privés. 


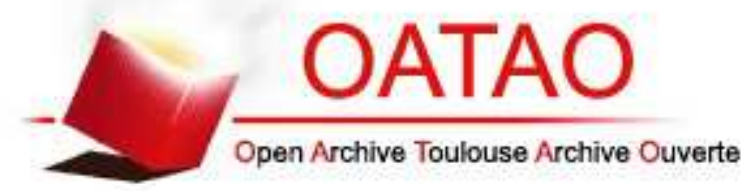

\section{Open Archive TOULOUSE Archive Ouverte (OATAO)}

OATAO is an open access repository that collects the work of Toulouse researchers and makes it freely available over the web where possible.

This is an author-deposited version published in : http://oatao.univ-toulouse.fr/ Eprints ID : 14500

To link to this article : doi: 10.1016/j.funeco.2015.05.014

URL : http://dx.doi.org/10.1016/i.funeco.2015.05.014

To cite this version : Chauvet, Eri and Cornut, Julien and Sridhar, Kandikere R. and Selosse, Marc-André and Bärlocher, Felix Beyond the water column: aquatic hyphomycetes outside their preferred habitat. (2016) Fungal Ecology, vol. 19. pp. 112-127. ISSN 1754-5048

Any correspondance concerning this service should be sent to the repository administrator: staff-oatao@ listes-diff.inp-toulouse.fr 


\title{
Beyond the water column: aquatic hyphomycetes outside their preferred habitat
}

\author{
Eric CHAUVET ${ }^{a, b, *}$, Julien CORNUT ${ }^{c, d}$, Kandikere R. SRIDHAR ${ }^{e}$, \\ Marc-André SELOSSE ${ }^{f}$, Felix BÄRLOCHER ${ }^{g}$ \\ ${ }^{a}$ Université de Toulouse, UPS, INPT, EcoLab (Laboratoire Ecologie Fonctionnelle et Environnement), \\ 118 route de Narbonne, 31062 Toulouse, France \\ ${ }^{\mathrm{b}} \mathrm{CNRS}$, EcoLab, 31062 Toulouse, France \\ ${ }^{c}$ Laboratoire Interdisciplinaire des Environnements Continentaux (LIEC), Université de Lorraine - UMR CNRS 7360, \\ Avenue du Général Delestraint, 57070 Metz, France \\ ${ }^{\mathrm{d}}$ CNRS, LIEC, $57070 \mathrm{Metz}$, France \\ e Department of Biosciences, Mangalore University, Mangalagangotri, 574199 Mangalore, India \\ IInstitut de Systématique, Évolution, Biodiversité (ISYEB - UMR 7205 - CNRS, MNHN, UPMC, EPHE), \\ Muséum National d'Histoire Naturelle, Sorbonne Universités, 57 rue Cuvier, CP50, 75005 Paris, France \\ gDepartment of Biology, Mount Allison University, Sackuille, NB E4L 1G7 Canada
}

\begin{abstract}
A B S T R A C T
Aquatic hyphomycetes have adapted to running waters by their uncommon conidial shape, which facilitates dispersal as well as adherence to plant substrata. However, they have been early and regularly reported to occur in a variety of environments other than their preferred habitat (e.g., in lentic freshwaters, brackish and marine environments, in terrestrial niches such as stream banks, dew, canopy waters and tree holes). In addition, several aquatic hyphomycetes have adapted to a mutualistic lifestyle which may involve plant defence, as endophytes in leaves, gymnosperm needles, orchids and terrestrial roots. There are several lines of evidence suggesting that aquatic hyphomycetes survive under terrestrial conditions due to their sexual states. Although exhibiting higher diversity in pristine streams, aquatic hyphomycetes can survive environmental stress, e.g., pollution or river intermittency. They also inhabit ground and hyporheic waters, where they appear to be subjected to both physical and physiological selection. Appropriate methods including molecular ones should provide a more comprehensive view of the occurrence and ecological roles of aquatic hyphomycetes outside their preferred habitat.
\end{abstract}

Keywords:

Aquatic hyphomycetes

Endophyte

Groundwater

Lentic habitat

Molecular methods

Soil

Tree canopy

* Corresponding author. Université de Toulouse, UPS, INPT, EcoLab (Laboratoire Ecologie Fonctionnelle et Environnement), 118 route de Narbonne, 31062 Toulouse, France. Tel.: +33 561558913; fax: +33 561558901.

E-mail address: eric.chauvet@univ-tlse3.fr (E. Chauvet).

http://dx.doi.org/10.1016/j.funeco.2015.05.014 


\section{Introduction}

Ingold's discovery of aquatic hyphomycetes, a diverse fungal community with predominantly tetraradiate (multiradiate) or sigmoid conidia, growing abundantly on deciduous leaves decaying in streams, shifted fungal research efforts toward running waters (Ingold, 1975; Bärlocher, 1992a). However, several, maybe a majority of, aquatic hyphomycetes occur in both aquatic and terrestrial habitats. Webster (1977), therefore, began referring to them as "aquatic" hyphomycetes, and Michaelides and Kendrick (1978) suggested that the more appropriate term for this group is "amphibious hyphomycetes". The most straightforward connection seems to be the occurrence of sexual reproduction when the still moist substratum (generally wood) is exposed to air. To our knowledge, nothing is known about the impact of sexually produced spores on the activity and composition of fungal populations in streams. In some circumstances, the presence of aquatic hyphomycetes in terrestrial habitats may be accidental, e.g., leaves fall into a stream and are colonized. Due to variable water flow, some leaves are subsequently deposited on the banks, on bare ground within the floodplain, even trapped on branches of riparian trees and bushes, or buried in the streambed sediment, and may eventually be returned to the actual stream. In these cases, survival of the dry period will be essential. Finally, it seems that terrestrial existence is a requisite or common occurrence for some fungi with stauroor scoleco-sporous conidia. These taxa may or may not be properly classified as aquatic hyphomycetes. They are found in (moist) leaf litter layers on the ground or in tree holes, and may be connected to species found in throughfall and stemflow. Potential sources for these species are phylloplane and endophytic fungi. In line with this variety of niches and physiological traits, Descals and Moralejo (2010) discussed possible terminologies for fungal groups with connections to aquatic habitats. The present review provides an insight into the various environments occupied by aquatic hyphomycetes apart from their main habitat, i.e., running waters (as illustrated in Fig 1), together with mechanisms involved in dispersal and colonization.

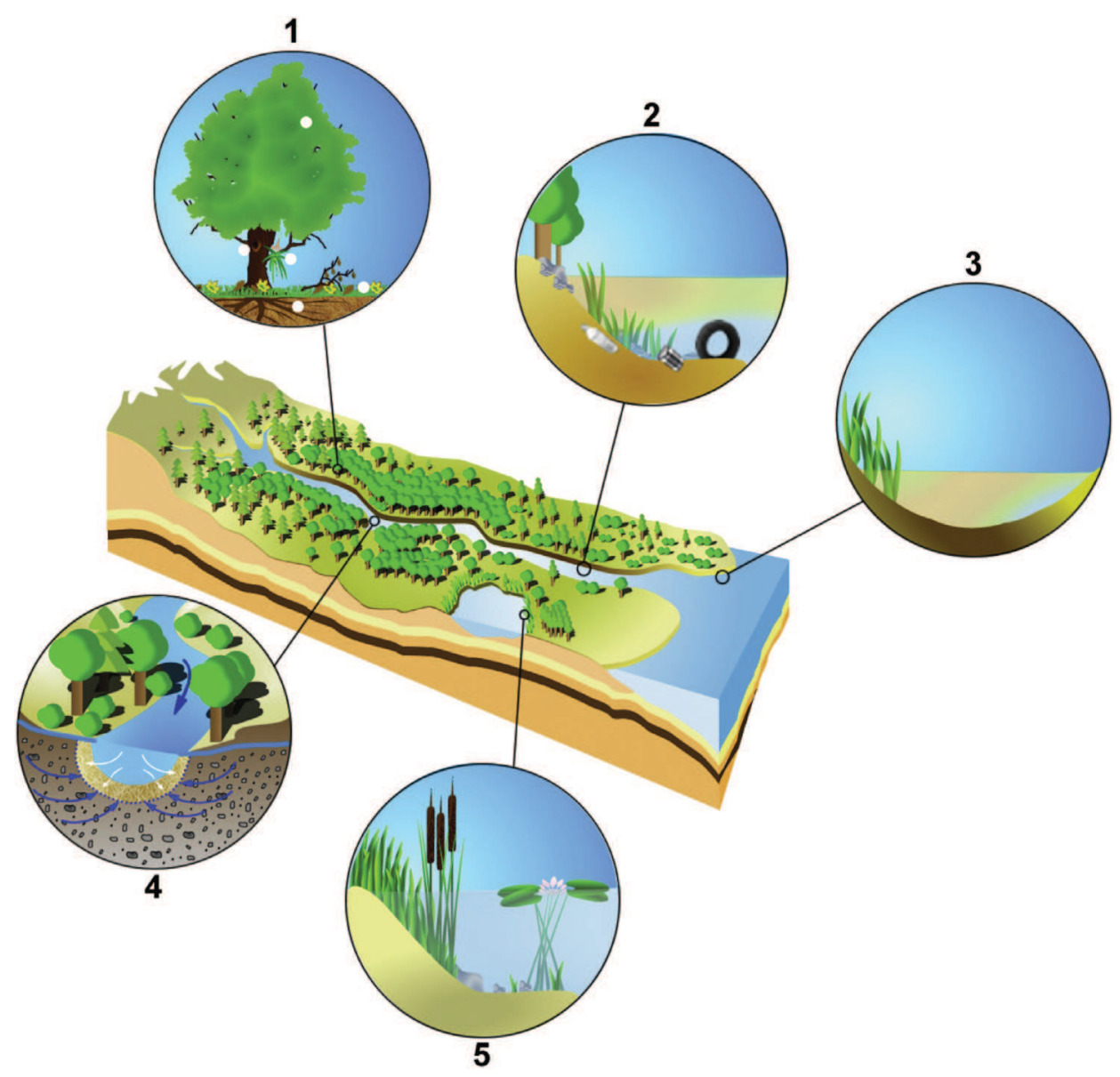

Fig 1 - Aquatic hyphomycetes have been reported from a wide variety of environments and niches, outside their preferred habitat (i.e., running waters): 1. Trees, including canopy, orchids, tree holes, roots, and forest floor, as illustrated by white dots (some occurring as endophytes in roots or needles, cf. Fig 2); 2. Stressed freshwaters; 3. Estuarine environments; 4. Hyporheic habitat and groundwaters; 5. Lentic waters. 


\section{Historical background}

The earliest records of fungi that can be considered aquatic hyphomycetes were from terrestrial environments (Bärlocher, 1992a). Thus, Heliscus lugdunensis was described from pine bark near Lyon and in northern Italy (Saccardo, 1880). In the same year, Hartig (1880) described Cercospora acerina parasitizing maple seedlings. This species is now known as Mycocentrospora acerina. It is a remarkably versatile species: it is a well-known plant pathogen, has been implicated in human infections and is a common stream fungus (Ingold, 1975). Morphologically, there are no consistent differences between the strains, and Iqbal and Webster (1969) showed that strains originating from a stream were pathogenic to carrots and parsnips. Nevertheless, molecular comparisons of pathogenic and saprotrophic forms are clearly overdue - there is only one published reference to ITS sequences of a pathogenic strain (Stewart et al., 1999). Of interest is Hartig's (1880) observation that dried up mycelia survived for up to $1 \mathrm{yr}$. De Wildeman in 1893, 1894 and 1895 described four more species of aquatic hyphomycetes (Bärlocher, 1992a) from ponds, ditches, and marshy areas. However, conidia of what are typical or possible aquatic hyphomycete species were also recorded from primarily terrestrial habitats, such as water films between leaf carpets, where Scourfield (1940) found Tetracladium setigerum (misidentified as Te. marchalianum), Tricellula ornithomorpha and several species of Fusarium. Well after Ingold's (1942) foundational paper, aquatic hyphomycetes have continued to be reported from terrestrial habitats (e.g., from roots, Waid, 1954; or from fallen Eucalyptus wood, Price and Talbot, 1966), with studies regularly discovering new niches together with potential mechanisms of persistence, dispersal and colonization of substrata out of rivers. A major breakthrough was Bandoni's (1972) method of flooding leaves collected from soil with sterile water. This released considerable numbers of spores, many of them sigmoid or tetraradiate and some identical to forms previously isolated from stream-exposed leaves. Bandoni and Koske (1974) suggested that these spores are dispersed by monolayer-forming substances present in aqueous films on terrestrial litter. Carroll (1981) noticed unusual (staurosporous) conidia in canopy throughfall, but Bandoni (1981) was the first to systematically examine spores in stemflow and throughfall, with some being morphologically similar or identical to those of common aquatic hyphomycetes.

\section{Survival out of water}

The distribution of leaves in a river is very dynamic, with leaves tending to accumulate in pools rather than in riffles, or being trapped as packs behind rocks or tree trunks. The streambed itself is often unstable, and some leaves may become buried (Herbst, 1980). Fluctuating water levels thus create a mosaic of aquatic, semi-aquatic and terrestrial habitats in a floodplain. As a consequence, the cycle of inundation and air exposure affects fungal biomass and litter decomposition rates. Generally, both decline rapidly during the terrestrial phase (Langhans and Tockner, 2006; Langhans et al., 2008; Leberfinger et al., 2010; Bruder et al., 2011).
Thakur (1977) collected submerged leaves from the River Dahisar (Maharashtra, India) and incubated them in sterile water to identify sporulating species. He then let the water evaporate and stored the dried leaves in sterile vials at room temperature. At $20 \mathrm{~d}$ intervals, the leaves were resubmerged in water and sporulating species were listed. Of six identified species, three survived for more than $100 \mathrm{~d}$ (maximum: $170 \mathrm{~d}$ ), and all survived for at least $30 \mathrm{~d}$. Survival was greater in halfskeletonized than in skeletonized leaves.

Sanders and Webster (1978) inoculated sets of oak leaf disks with one of ten pure cultures and exposed them on two terrestrial sites (with the nearest stream 20 or $200 \mathrm{~m}$ away). All ten species could be recovered after 8 weeks of exposure, and two survived for at least 12 months. Leaves exposed up to $1.5 \mathrm{~m}$ above the normal river level following flooding were also sampled and examined for the presence of aquatic hyphomycetes. After 13 weeks, five species were present; after 17 weeks, none could be recovered. A similarly rapid extinction was observed on artificially inoculated disks. Only Anguillospora crassa survived for 15 weeks, three more species did not survive beyond 12 weeks. The remaining six species did not survive beyond 8 weeks. The ability to spread to adjacent leaves was only observed with Articulospora tetracladia and Varicosporium elodeae. Overall, there was some ability to survive desiccation for a few weeks to months, but the ability to spread within the litter layer seemed limited.

Khan (1986) exposed agar disks overgrown with a pure culture and dried them in a desiccator for 1 week; they were then tested for viability. In addition, mycelial pellets from broth cultures were dried and retrieved weekly for up to 12 weeks. Finally, conidia were deposited on cellophane and placed in a desiccator. In general, conidia were most vulnerable to xeric conditions: the estimated half-life varied between $12 \mathrm{~s}$ and $900 \mathrm{~min}$. Survival of mycelia in agar blocks was generally poor, while pelleted mycelia remained viable for between 4 and 12 weeks.

Thus, experimental studies suggest that while aquatic hyphomycetes artificially exposed to dry conditions can survive for several weeks to months, their activity and dispersal are quite limited under these conditions.

\section{Forest floor}

Bandoni (1972) was the first to document appreciable numbers of conidial shapes normally associated with aquatic hyphomycetes in terrestrial litter, which he submerged in distilled water. He isolated 9 species assigned to that group (among them Alatospora, Articulospora, and Tetracladium). Others may have been equally common in soil and in streams: e.g., V. elodeae (Kegel, 1906; Bessey, 1939; Waid, 1954; Mäkelä, 1972) and Volucrispora graminea = Ypsilina graminea (Mäkelä, 1972; Ingold, 1975). Species of a third group were predominantly terrestrial. Using Bandoni's (1972) approach, Koske and Duncan (1974) isolated additional colonies from dry, welldrained sites at some distance from water bodies. Park (1974) summarized some of the early work and observed additional spores on clean glass slides buried in the soil.

To evaluate the importance of distance to a stream, Webster (1977) collected leaf samples in a steeply sloping 
forest at $10 \mathrm{~m}$ intervals from the bank of the river. Leaves were placed in distilled water and scanned for the appearance of spores and conidiophores. In total, 17 species were observed. More spores were observed on leaves that had been on the ground for several months. The frequency of occurrence of spores and conidiophores decreased rapidly with distance from the stream.

In a similar study in Nova Scotia, Canada, Sridhar and Bärlocher (1993) found a total of 33 species with multiradiate or sigmoid spores, and 26 species from the stream itself. The number of species per site was highest on leaves collected from the stream, followed by leaves from two periodically flooded sites and finally from sites farthest from the stream that were never covered by water. The decline in fungal diversity, however, was less steep than in Webster's (1977) study. Possibly, the colder climate with extended periods of snow cover may have mitigated some of the differences between terrestrial and aquatic habitats.

Multiradiate or sigmoid spores, many of them belonging to common aquatic hyphomycetes, were also produced on leaves collected from the banks of two streams in India (Sridhar and Kaveriappa, 1987), and at terrestrial sites at some distance from streams in Sierra Leone (Singh and Musa, 1977), in Kentucky, Tennessee, Georgia and North Carolina (Dyko, 1976), in Hawaii (Goos, 1978), and in England and Jamaica (Hudson and Sutton, 1964).

Bandoni (1974) drew attention to the microlayer, an air-water interface with surface-active substances. In terrestrial habitats, such layers frequently occur on surfaces of decaying leaves or other litter, and are often rich in living organisms, among them fungal spores (Scourfield, 1940). Bandoni (1981, 1974) developed a simple floatation method to collect these spores: the litter is submerged in a narrow cylinder, a clean coverslip is then touched to the water surface, which collects much of the surface film and its organisms. Surface-active substances spreading on the water film can transport floating spores to water films on adjacent leaves or plant detritus (Bandoni and Koske, 1974). This mechanism can even result in some "upward migration", a concept introduced earlier by Lackey (1940) to explain the terrestrial distribution of several aquatic organisms.

\section{Forest canopy: phytothelms, stemflow and throughfall}

The forest canopy is the functional interface between up to $90 \%$ of global terrestrial biomass and the atmosphere (Ozanne et al., 2003). It is a structurally complex and ecologically dynamic subsystem, allowing niche diversification and providing scope for evolution of life forms in flora, fauna and microorganisms that are not usually found on the forest floor (Hammond et al., 1977; Nadkarni et al., 2001; Ozanne et al., 2003). Canopies, which trap organic matter, like leaf litter, twigs, and inflorescences, and convert them into crown humus, afford a variety of niches that harbour aquatic hyphomycetes (Table 1). In total, these fungi have been found in the canopies of 57 plant species (Table 2). While these studies revealed a number of morphologically varied shapes of conidia similar to those in aquatic habitats, between 15 and $20 \%$ of aquatic hyphomycete-like conidia reported from canopies were not fully identified. Thorough studies, as done in aquatic habitats with molecular approaches, may fill in these lacunae.

Gönczöl (1976) was the first to look for aquatic hyphomycetes in tree holes or hollows, which often trap water, detritus such as leaves, and sediment. During heavy rains, the biotope in such tree holes may correspond to a flow chamber, and resemble a running water habitat. Gönczöl (1976) found large numbers of spores in the water, many belonging to Alatospora

Table 1 - Ganopy niches for aquatic hyphomycetes

\begin{tabular}{|c|c|c|}
\hline Niche & Country & Reference \\
\hline Live leaves & India, Japan, Hungary, Poland & $\begin{array}{l}\text { Ando and Kawamoto, 1986; Ando and Tubaki, 1984a, 1984b; Czeczuga and } \\
\text { Orłowska, 1998a, 1994; Gönczöl and Révay, 2004, 2003; Gönczöl, 1976; } \\
\text { Karamchand and Sridhar, 2009; Sridhar et al., 2006; Sudheep and Sridhar, } \\
2010\end{array}$ \\
\hline Live needles & Canada & Sokolski et al., 2006 \\
\hline Live twigs & Hungary & Révay and Gönczöl, 2011 \\
\hline Live rhizomes (ferns) & India & Karamchand and Sridhar, 2009; Sridhar et al., 2006 \\
\hline Live roots (orchids) & Estonia, Germany, India, Italy & $\begin{array}{l}\text { Abadie et al., 2006; Elena et al., 2010; Karamchand and Sridhar, 2009; } \\
\text { Sridhar et al., 2006; Stark et al., } 2009\end{array}$ \\
\hline Tree holes & Hungary, India, United States & $\begin{array}{l}\text { Gönczöl and Révay, 2004, 2003; Gönczöl, 1976; Karamchand and Sridhar, } \\
\text { 2009, 2008; Kaufman et al., 2008; Sridhar et al., } 2013\end{array}$ \\
\hline Sediment (in tree holes) & India & Sudheep and Sridhar, 2010 \\
\hline Stemflow & $\begin{array}{l}\text { Canada, Germany, Hungary, } \\
\text { India, Japan, Poland }\end{array}$ & $\begin{array}{l}\text { Ando and Kawamoto, 1986; Ando and Tubaki, 1984b; Bandoni, 1981; } \\
\text { Czeczuga and Orłowska, 1999, 1994; Gönczöl and Révay, 2006, 2004; } \\
\text { Mackinnon, 1982; Sridhar and Karamchand, 2009; Sudheep and Sridhar, } \\
2010\end{array}$ \\
\hline Throughfall & $\begin{array}{l}\text { Canada, Hungary, India, } \\
\text { Romania, Sweden }\end{array}$ & $\begin{array}{l}\text { Bandoni, 1981; Gönczöl and Révay, 2006; MacKinnon, 1982; Révay and } \\
\text { Gönczöl, 2010; Sridhar and Karamchand, 2009; Sudheep and Sridhar, } 2010\end{array}$ \\
\hline Honey dew & Croatia, Greece, Italy & Magyar et al., 2005; Sridhar et al., 2006 \\
\hline Floral honey & South Africa & Magyar et al., 2005 \\
\hline Snow (deposited on canopy) & Poland & Czeczuga and Orłowska, 1998b \\
\hline
\end{tabular}


Table 2 - Plant species that yield aquatic hyphomycetes in the canopy

\begin{tabular}{|c|c|c|c|}
\hline Plant species & Sample & Country & Reference \\
\hline Acacia auriculiformis & Stemflow and throughfall & India & Sridhar and Karamchand, 2009 \\
\hline Acer macrophyllum & Stemflow & Canada & Bandoni, 1981 \\
\hline Alnus glutinosa & Accumulated rain water and live twigs & Hungary & $\begin{array}{l}\text { Gönczöl and Révay, 2006; } \\
\text { Révay and Gönczöl, } 2011\end{array}$ \\
\hline Alnus rubra & Stemflow & Canada & Bandoni, 1981 \\
\hline Alstonia scholaris & Stemflow and throughfall & India & Sridhar and Karamchand, 2009 \\
\hline Artocarpus heterophyllus & $\begin{array}{l}\text { Stemflow, throughfall, trapped leaf litter } \\
\text { and sediment in tree holes }\end{array}$ & India & Sudheep and Sridhar, 2010 \\
\hline Artocarpus integrifolius & Stemflow and throughfall & India & Sridhar and Karamchand, 2009 \\
\hline Carallia brachiata & Stemflow and throughfall & India & Sridhar and Karamchand, 2009 \\
\hline Careya arborea & Stemflow and throughfall & India & Sridhar and Karamchand, 2009 \\
\hline \multirow[t]{2}{*}{ Carpinus betulus } & Accumulated rain water & Germany & Gönczöl and Révay, 2006 \\
\hline & Live twigs & Hungary & Révay and Gönczöl, 2011 \\
\hline Cassia fistula & $\begin{array}{l}\text { Stemflow, throughfall, trapped leaf litter } \\
\text { and sediment in tree holes }\end{array}$ & India & Sudheep and Sridhar, 2010 \\
\hline Cephalanthera longifolia & Live roots & Estonia & Abadie et al., 2006 \\
\hline Chamaecyparis lawsoniana & Stemflow, throughfall and live twigs & Hungary & $\begin{array}{l}\text { Gönczöl and Révay, 2004; } \\
\text { Révay and Gönczöl, 2011, } 2010\end{array}$ \\
\hline Cupressus arizonica & Throughfall & Hungary & Révay and Gönczöl, 2010 \\
\hline Drynaria quercifolia & Various live tissues & India & $\begin{array}{l}\text { Karamchand and Sridhar, 2009; } \\
\text { Sridhar et al., } 2006\end{array}$ \\
\hline Eucalyptus tereticornis & Stemflow and throughfall & India & Sridhar and Karamchand, 2009 \\
\hline Fagus grandifolia & Tree holes & United States & Kaufman et al., 2008 \\
\hline \multirow[t]{2}{*}{ Fagus sylvatica } & Accumulated rain water & Germany & Gönczöl and Révay, 2006 \\
\hline & $\begin{array}{l}\text { Accumulated rain water, stemflow, throughfall, } \\
\text { tree holes and live twigs }\end{array}$ & Hungary & $\begin{array}{l}\text { Gönczöl and Révay, 2006, 2004, } \\
\text { 2003, 1996; Révay and Gönczöl, } 2011\end{array}$ \\
\hline Ficus benghalensis & $\begin{array}{l}\text { Stemflow, throughfall and natural leaf litter } \\
\text { in tree holes }\end{array}$ & India & $\begin{array}{l}\text { Karamchand and Sridhar, 2008; } \\
\text { Sridhar and Karamchand, } 2009\end{array}$ \\
\hline Ficus recemosa & $\begin{array}{l}\text { Stemflow, throughfall, trapped leaf litter } \\
\text { and sediment in tree holes }\end{array}$ & India & Sudheep and Sridhar, 2010 \\
\hline Ficus religiosa & Stemflow and throughfall & India & Sridhar and Karamchand, 2009 \\
\hline Fraxinus excelsior & Tree holes & Hungary & Gönczöl and Révay, 2003 \\
\hline Gymnadenia conopsea & Live roots & Germany & Stark et al., 2009 \\
\hline Holigarna ferruginea & Natural and immersed leaf litter in tree holes & India & $\begin{array}{l}\text { Karamchand and Sridhar, 2008; } \\
\text { Sridhar et al., } 2013\end{array}$ \\
\hline Juniperus communis & Live twigs & Hungary & Révay and Gönczöl, 2011 \\
\hline Koelreuteria paniculata & Stemflow and throughfall & Hungary & Gönczöl and Révay, 2004 \\
\hline Macaranga peltata & Natural leaf litter in tree holes & & Karamchand and Sridhar, 2008 \\
\hline Mangifera indica & $\begin{array}{l}\text { Stemflow, throughfall and natural leaf } \\
\text { litter in tree holes }\end{array}$ & India & $\begin{array}{l}\text { Karamchand and Sridhar, 2008; } \\
\text { Sridhar and Karamchand, } 2009\end{array}$ \\
\hline Morus alba & Stemflow and throughfall & Hungary & Gönczöl and Révay, 2004 \\
\hline Odina wodier & Stemflow and throughfall & India & Sridhar and Karamchand, 2009 \\
\hline Orchis militaris & Live root & Italy & Elena et al., 2010 \\
\hline \multirow[t]{2}{*}{ Picea abies } & Accumulated rain water & Romania, Sweden & Gönczöl and Révay, 2006 \\
\hline & Throughfall & Hungary & Révay and Gönczöl, 2010 \\
\hline Picea mariana & Live needles & Québec (Canada) & Sokolski et al., 2006 \\
\hline Pinus nigra & Live twigs & Hungary & Révay and Gönczöl, 2011 \\
\hline Picea pungens & Throughfall & Hungary & Révay and Gönczöl, 2010 \\
\hline \multirow[t]{2}{*}{ Pinus sylvestris } & Accumulated rain water & Sweden & Gönczöl and Révay, 2006 \\
\hline & Throughfall and live twigs & Hungary & Révay and Gönczöl, 2011, 2010 \\
\hline Platanus hybrida & Stemflow and throughfall & Hungary & Gönczöl and Révay, 2004 \\
\hline Pongamia glabra & Stemflow and throughfall & India & Sridhar and Karamchand, 2009 \\
\hline Populus tremuloides & Stemflow and throughfall & Canada & MacKinnon, 1982 \\
\hline Prunus avium & Accumulated rain water & Germany & Gönczöl and Révay, 2006 \\
\hline Quercus cerris & Accumulated rain water & Hungary & Gönczöl and Révay, 2006 \\
\hline Quercus macrocarpa & Stemflow and throughfall & Hungary & Gönczöl and Révay, 2004 \\
\hline Quercus rubra & Dead wood & Germany & Unterseher et al., 2005 \\
\hline Quercus sp. & Tree holes & Hungary & Gönczöl and Révay, 2003 \\
\hline Salix matsudana & Stemflow and throughfall & Hungary & Gönczöl and Révay, 2004 \\
\hline Sophora japonica & Stemflow and throughfall & Hungary & Gönczöl and Révay, 2004 \\
\hline Syzygium caryophyllatum & $\begin{array}{l}\text { Stemflow, throughfall, trapped leaf } \\
\text { litter and sediment in tree holes, immersed } \\
\text { leaf litter in tree holes }\end{array}$ & India & $\begin{array}{l}\text { Karamchand and Sridhar, 2008; } \\
\text { Sridhar et al., 2013; Sudheep and } \\
\text { Sridhar, } 2010\end{array}$ \\
\hline
\end{tabular}




\begin{tabular}{|c|c|c|c|}
\hline Plant species & Sample & Country & Reference \\
\hline Syzygium cumini & Stemflow and throughfall & India & Sridhar and Karamchand, 2009 \\
\hline Swida controversa & Phyllosphere & Japan & Osono and Mori, 2004 \\
\hline Taxus baccata & $\begin{array}{l}\text { Accumulated rain water, stemflow, } \\
\text { throughfall and live twigs }\end{array}$ & Hungary & $\begin{array}{l}\text { Gönczöl and Révay, 2006, 2004; } \\
\text { Révay and Gönczöl, 2011, } 2010\end{array}$ \\
\hline Tectona grandis & Stemflow and throughfall & India & Sridhar and Karamchand, 2009 \\
\hline Terminalia paniculata & Stemflow and throughfall & India & Sridhar and Karamchand, 2009 \\
\hline Thuja occidentalis & Throughfall & Hungary & Révay and Gönczöl, 2010 \\
\hline Thuja plicata & Stemflow & Canada & Bandoni, 1981 \\
\hline Tilia cordata & Stemflow and throughfall & Hungary & Gönczöl and Révay, 2004 \\
\hline Vaccinium myrtillus & Throughfall & Hungary & Révay and Gönczöl, 2010 \\
\hline Xylia xylocarpa & $\begin{array}{l}\text { Stemflow, throughfall, trapped leaf } \\
\text { litter and sediment in tree holes }\end{array}$ & India & Sudheep and Sridhar, 2010 \\
\hline
\end{tabular}

acuminata, Ar. tetracladia and Camposporium pellucidum. The first two are common aquatic hyphomycetes, the third is generally considered to be primarily terrestrial, though it has been observed sporulating on leaves recovered from a stream (Ingold, 1975). In a later study, Gönczöl and Révay (1983) compared fungi from forest litter and tree-hollows to earlier reports from stream litter. They distinguished a total of 32 species, but were often unable to decide whether they were 'aquatic' or 'terrestrial'. Nevertheless, they reported many species that are commonly found in streams. Some were observed in almost all samples, though their abundances were generally greatly reduced on terrestrial leaves. In beech, oak, and ash tree holes, Gönczöl and Révay (2003) detected 45 hyphomycete species, with Al. acuminata being the most common while others were clearly terrestrial (e.g., Alternaria) or aero-aquatic (e.g., Helicodendron tubulosum). More recently, Kaufman et al. (2008) reported that Dimorphospora foliicola, an aquatic hyphomycete, was the most common fungal taxon in beech (Fagus) tree holes in Michigan. Karmanchand and Sridhar (2008) who compared fungal taxa during the dry and wet (monsoon) season in India found that the amount and diversity of conidial output from incubated tree hole leaves were generally lower than those from stream leaves. Again, several species corresponded to typical stream fungi, while the season significantly affected conidial diversity in both sites examined. In a controlled study, fungal diversity, conidial production and mycelial biomass on leaves exposed in tree holes and in a stream were similar (Sridhar et al., 2013), however, decay rates were considerably lower in the tree holes. Finally, sediment and leaves trapped on five common riparian tree species yielded a total of 29 species (Sudheep and Sridhar, 2010).

Epiphytic ferns often trap leaf litter and water, which again provide a fungal habitat (Karamchand and Sridhar, 2009; Sridhar et al., 2006). Aquatic hyphomycetes were present on fern leaves and roots, and on leaves trapped from the tree canopy. Generally, both conidial output and fungal diversity were greater on fern leaves than on trapped leaves, but lower than in adjacent streams. Including earlier reports, Sridhar et al. (2006) concluded that a total of 65 species of aquatic hyphomycete and aquatic hyphomycete-like fungi had been recovered from tree canopies. Another potential habitat colonized by aquatic hyphomycetes is orchids housed in tree canopies. Sequences of Tetracladium were reported in orchid roots of Cephalanthera longifolia and Gymnadenia conopsea in temperate regions (Abadie et al., 2006; Stark et al., 2009). Further, based on ITS analysis, the occurrence of Tetracladium was documented in roots of Orchis militaris in Northern Italy (Elena et al., 2010). Finally, like orchids in canopies and tree holes, tank-bromeliads are a type of phytothelms (Brouard et al., 2012; Kitching, 1971) that form miniature detrital ecosystems. They may also shelter aquatic hyphomycetes, though to our knowledge none have been reported as yet.

When monitoring water flowing down stems (stemflow), Bandoni (1981) identified spores, some of which belonged to Gyoerffyella biappendiculata, the only species he considered a true aquatic hyphomycete. Bandoni (1981) also examined rainwater or mist dripping from foliage to the ground (throughfall), and found Tripospermum spp. to be most abundant. Spores typical of stream hyphomycetes were also common (e.g., Alatospora, Articulospora, Tricladium, Varicosporium). He concluded that some aquatic hyphomycetes actively grow and sporulate in terrestrial litter and soil and are present in rainwater collected in gutters or flowing down trees. The same habitats, however, are also rich in numerous other staurosporous and scolecosporous conidia that could not be connected to common aquatic hyphomycetes which dominate leaf decomposition in streams. A spore shape by itself is, therefore, a poor indicator of the preferred habitat of a fungus (Descals and Moralejo, 2010). More complex shapes may facilitate attachment in running waters (as in aquatic hyphomycetes); (Dang et al., 2007; Kearns and Barlocher, 2008), but may also be an adaptation to dispersal in biofilms in terrestrial habitats (Bandoni and Koske, 1974) or to hold water for as long as possible. This will increase the probability of successful germination of the fragile and easily desiccated conidia (Ando, 1992).

Based on the discovery of stemflow and throughfall conidia, Carroll (1981) postulated the existence of a guild of fungi that may "function in canopies much as classical Ingoldian aquatic hyphomycetes in streams". He labelled them "canopy fungi or arboreal aquatic hyphomycetes", and noted that none of the phylloplane studies had recorded these fungi. Ando (1992) used the term "terrestrial aquatic hyphomycetes" for species whose staurosporous conidia resembled those of typical aquatic hyphomycetes but were apparently absent 
from leaves decaying in streams. They generally lack conidiophores or are conspicuously micronematous. Many studies have since demonstrated the near universal presence of both typical aquatic hyphomycete and other morphologically complex conidia in rainwater from throughfall, stemflow, urban building roofs, and morning dew (Mac Kinnon, 1982; Ando and Tubaki, 1984a; Tubaki et al., 1985; Ando, 1992; Czeczuga and Orłowska, 1994, 1998a, 1999; Gönczöl and Révay, 2004, 2006; Sridhar, 2009; Sridhar and Karamchand, 2009). They also occur in floral and honeydew honeys, raising the intriguing possibility that some may have been preserved in amber. Lists and illustrations of many of these canopy fungi are found in Gönczöl and Révay $(2004,2006)$ and Sridhar (2009). Presumably, they exist on organic matter shed by the trees (leaves, twigs, inflorescences) and transform it into "crown humus", but almost nothing is known about the details of this process.

How do aquatic hyphomycetes colonize litter trapped in tree holes or epiphytic plants? Some may be present as endophytes in trees or ferns (e.g., Karamchand and Sridhar, 2009), others may live and reproduce in the phylloplane. Regardless of origin, there is a substantial downward transport of fungal spores through stemflow and throughfall. Canopy fungi thus face the same problem as aquatic hyphomycetes in running waters: spores are non-motile, and passive transport is dominated by rainwater flowing toward the soil. Thus, there must be dispersal mechanisms of aquatic hyphomycete conidia from aquatic to non-aquatic habitats and vice versa. Several aquatic hyphomycete species reproduce sexually (first recorded by Ranzoni, 1956); their teleomorphs are typically produced on moist, but not submerged, twigs and branches, and teleospores are likely to be transmitted aerially as well as by water currents (Webster, 1992). In addition to dispersal of spores through perfect states, loose conidia on leaf surfaces or in foam cakes may escape as aerosol and be transported by wind or fog over extended distances to the foliar surfaces or other terrestrial substrata (Selosse et al., 2008). It is possible (though untested) that aerosols carry the conidia and redistribute them to substrata over a wide geographic area. Conidia present in stemflow and throughfall accumulate on dead organic matter on the floor which they may colonize as long as moisture prevails; during drier periods they may survive as mycelia embedded within the dead tissues.

\section{Aquatic hyphomycetes as endophytes}

Perhaps the most unexpected niche for (at least some) aquatic hyphomycetes is endophytism (Fig 2). Endophytes colonize plant tissues, generally without causing any damage or symptom (Wilson, 1995). Their impact on the host may range from neutral or profitable to weakly deleterious. The occurrence of aquatic hyphomycetes in roots growing in or near water has been demonstrated repeatedly by cultivation methods (e.g., Sati and Belwal, 2005; Bärlocher, 2006). Molecular barcoding also revealed several aquatic hyphomycetes at greater distance from water: Tetracladium-related sequences were reported in ectomycorrhizal roots (Murat et al., 2005), in the liverwort Marchantia foliacea (Russell and Bulman, 2005), in mycorrhizal orchid roots (Abadie et al., 2006; Elena et al., 2010; Stark et al., 2009), and in ericaceous plants (Tedersoo et al., 2007). Beyond these herbs, aquatic hyphomycetes may be endophytes in trees or ferns (e.g., Fisher and Petrini, 1990; Karamchand and Sridhar, 2009), and next generation sequencing methods have further facilitated their detection (e.g., Tetracladium and Gyoerffyella in Bistorta vivipara roots; Davey et al., 2015). Aquatic hyphomycetes like Dwayaangam
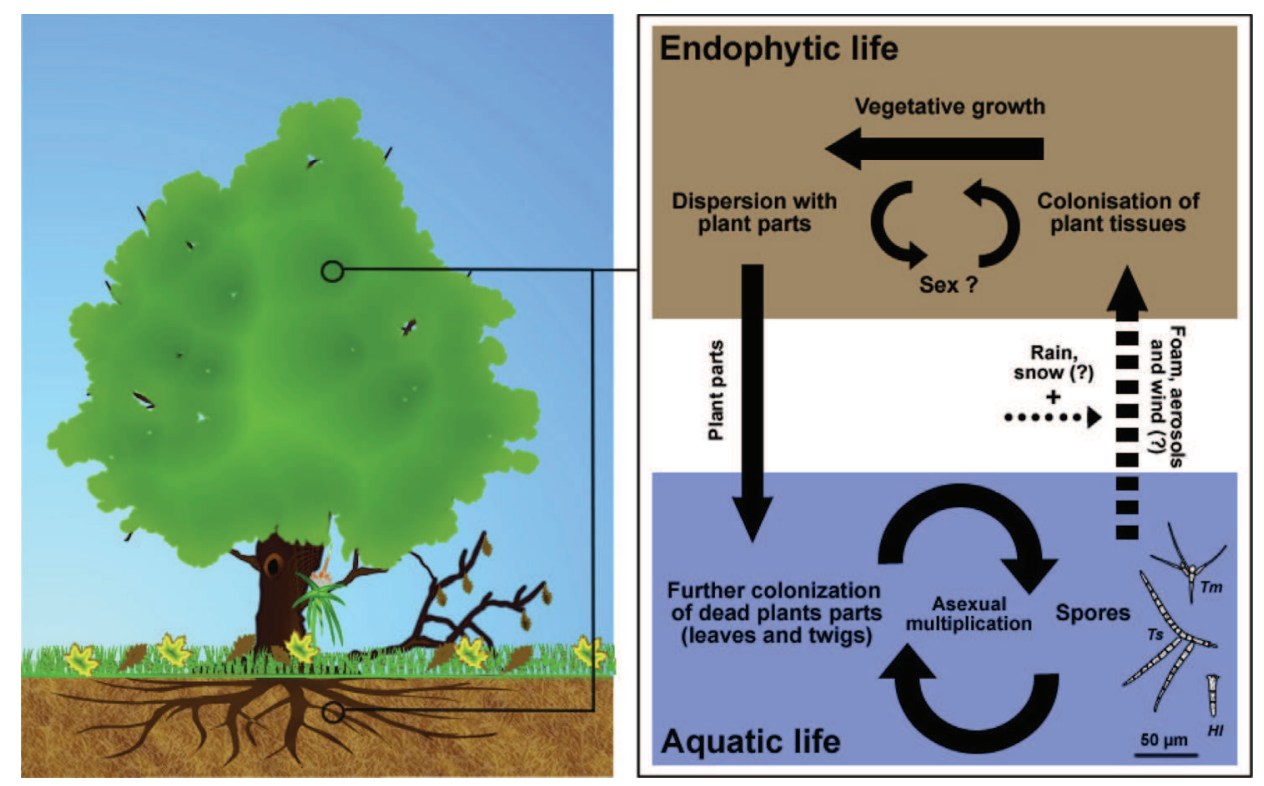

Fig 2 - Aquatic hyphomycetes may have a double life in terrestrial and aquatic environments, i.e. as endophytes in plant aerial parts and roots and saprotrophs on plant detritus in streams and rivers, respectively. Possible mechanisms of transfer from/to live and dead plant tissues are illustrated. From Selosse et al. (2008) with the permission of the New Phytologist. 
colodena, Tripospermum camelopardus and Tr. myrti are common endophytes in spruce (Picea mariana) needles in forests of Canada (Sokolski et al., 2006), and several Gyoerffyella strains were isolated from ectomycorrhizal P. abies roots (Vohník et al., 2013). A review of aquatic hyphomycetes with possible endophytic abilities can be found in Seena and Monroy (2016).

A major breakthrough in demonstrating the dual ecology of some aquatic hyphomycetes was the isolation of Dwayaangam strains from surface-sterilized spruce needles (P. mariana) by direct culture on solid agar medium, and after incubation in a flow chamber mimicking a running water environment (Sokolski et al., 2006). Both approaches recovered strains with similar molecular barcodes and asexual spores. This dual ecology may explain why, even without added inoculum, aquatic hyphomycetes appear on leaves collected from trees and submersed in distilled water (see Bandoni, 1972, and references therein). It was this observation that suggested to Bandoni (1972) that aquatic hyphomycetes were endophytes in aerial plant tissues.

Based on the phylogeny of the genus Tetracladium, where DNA sequences from endophytes and aquatic species intermingle, Selosse et al. (2008) proposed that postulating dual endophytic and aquatic abilities in the common ancestor is the most parsimonious explanation. A similar, more comprehensive approach (Seena and Monroy, 2016) supports the same trend in many clades. The question of the evolutionary direction (from saprotrophy to endophytism, or vice versa) remains open, but a closer phylogenetic analysis of all involved clades, including a representative sample of sister clades, may help to answer this question in the future. Similarly, the possible contribution of endophytic strains to strains observed in canopies remains to be assessed.

The documentation of an endophytic life style in aquatic hyphomycetes may surprise many mycologists. This shift from saprotrophy to biotrophy places aquatic hyphomycetes not only outside their preferred habitat, but also outside their traditional nutritional niche. However, several other taxa also occupy a dual, saprotrophic and endophytic niche (PorrasAlfaro and Bayman, 2011), among them Xylariaceae (Davis et al., 2003), some Sebacinales (Weiss et al., 2015), or even the lichen-forming fungi of the Stictis-Conotrema complex (Wedin et al., 2004). Most strikingly, Metarhizium, a common plant endophyte, is also a pathogen providing nitrogen recovered from dead insects to plant hosts (Behie et al., 2012). On an epistemological note, such dual niches are only surprising due to the conventional approach in mycology, where different teams handle pathogenic, saprotrophic, or endophytic fungi. The fungal niches have been arbitrarily delineated and apparently many fungi do not follow the a priori partition of niches.

Finally, research on fungi with saprotrophic and endophytic properties has entered the genomic era: the limited data available for Sebacinales and Tulasnellales (Kohler et al., 2015; Zuccaro et al., 2014, 2011) suggest that such fungi cumulate a large set of gene families encoding hydrolytic enzymes (common to saprotrophs but rare in pure biotrophs), as well as an expansion of the gene for putative effector proteins that modify host cell functioning (usually characterizing biotrophy). An exciting perspective is to verify whether aquatic hyphomycetes with endophytic abilities have also cumulated such features, and we thus call for the sequencing of more strains of endophytic aquatic hyphomycetes.

\section{Lentic and estuarine habitats - stressed freshwaters}

The strongly unidirectional flow is a defining feature of streams and rivers. This introduces a bias in the dispersal of running water inhabitants such as invertebrates, algae and fungi (Bärlocher, 1992b). It raises the question of how populations can persist in a given stream reach - the "drift paradox". For motile invertebrates, Müller (1982) suggested compensatory upstream flight by ovipositing adults ("colonization cycle"). In discussing aquatic hyphomycetes, Ingold (1975) stated: "The whole life history, vegetative growth, spore production and spore liberation and local dispersal, takes place in water". These fungi do not have any actively moving life stage. Nevertheless, they can be found close to stream sources and in springs, though conidial numbers and species diversity are generally low and increase in downstream reaches (Suberkropp et al., 1988; Fabre, 1998). Part of the answer may lie in the fact that despite the downstream bias, solutes and particles (spores, fungal-colonized leaf particles) do move upstream by advection-diffusion processes. Spores or mycelia of aquatic hyphomycetes may also be carried on or in actively moving animals (e.g., in guts of leafeating invertebrates; Bärlocher, 1981; conidia of Te. setigerum have been documented on a collembola; Price and Talbot, 1966).

Depending on the balance between upstream and downstream movements and growth or production rates, persistence of a fungal species in a given stream reach may be ensured without the need to invoke additional mechanisms (Lutscher et al., 2007; Pachepsky et al., 2005). It is more likely to be achieved, however, when the life history extends beyond the stream proper and there are population reservoirs in habitats outside the stream. These include the space underneath the stream bed (hyporheic habitat), the riparian region, and forests and soils at some distance from the stream. Transport of fungal-colonized detritus or fungal propagules by surface or subsurface water flow or through the atmosphere may replenish stream populations. Even though teleospores are more likely to be dispersed in the atmosphere, there is at least one report on the presence of aquatic hyphomycete conidia in air-spora (Tetracladium sp., Tetraploa aristata; Gregory and Hirst, 1957).

With the provision of a rich inoculum from upstream, the downstream reaches of rivers are expected to harbour aquatic hyphomycetes as well. The typical substrata of aquatic hyphomycetes, i.e., litter from trees and ligneous terrestrial vegetation, however, are progressively less abundant as rivers become larger (Vannote et al., 1980). In such environments, primary production (algae, aquatic and semi-aquatic plants) is mostly autochthonous, and aquatic hyphomycetes are not good colonizers of macrophytes, even though rare studies have reported their occurrence on macrophyte detritus (Kirby et al., 1990; Schlickeisen et al., 2003). Riparian forests may, however, provide substantial amounts of leaf litter and wood even in estuarine habitats. Recent observations showed that 
huge pulses of decomposed leaf litter originating far upstream can reach lower sections of estuaries (e.g., Gironde). However, the environment (very high turbidity, increased salinity, low oxygen concentration, etc.) selects and aquatic hyphomycetes of such decomposed litter remained undetectable using traditional methods (Fuentes-Cid et al., 2014). The lower oxygen concentration in estuaries (reduced turbulence and water velocity coupled with high turbidity) may decrease the level of activity and diversity of aquatic hyphomycetes encountered in streams and rivers (Pascoal and Cássio, 2004). The detrimental effect of low oxygen has been supported experimentally (Medeiros et al., 2009). Nonetheless, fungal survival in brackish and sea water together with a higher sensitivity of reproduction than biomass accrual to salinity have already been documented (cf. Bärlocher, 1992b). The latter pattern and the leaf-decomposing activity of aquatic hyphomycetes have been reported along a moderate gradient of salinity (3-14\%) in brackish waters of a Moroccan Mediterranean river (Maamri et al., 2006). If aquatic hyphomycetes are transported to the open ocean, they do not seem to develop or even survive in such environments. Among the few studies reporting their occurrence in marine habitats, e.g., as seaweed colonizers or in sea foam, some refer to species that do not correspond to known Ingoldian fungi suggesting that such marine "aquatic hyphomycetes" and their freshwater counterparts have developed somewhat convergent strategies and morphological adaptations. Recent investigations on the microbiota of sunken wood or intertidal wooden substrata however suggest possible occurrence of some Ingoldians (e.g., V. delicatum, Rämä et al., 2014; Kalenitchenko et al., 2015).

Swamps, ponds, lakes and river dead-arms are semiaerobic environments where aquatic hyphomycetes are much less abundant, while their counterparts on submerged plant litter, i.e., aero-aquatic hyphomycetes, tend to dominate. Unlike aquatic hyphomycetes, they sporulate once plant detritus subject to anaerobic conditions (illustrated by their blackened appearance) are exposed to air, with the produced buoyant conidia being dispersed at the water surface (Park, 1972). As a consequence, their survival in anaerobic conditions is much higher than that of aquatic hyphomycetes (Field and Webster, 1983). Due to these contrasting traits and requirements, aquatic and aero-aquatic hyphomycetes do not generally occupy the same habitats. However, aquatic hyphomycetes are regularly observed in riverine environments, including oxbow lakes and floodplain ponds more or less connected to the river channel. Again, the diversity of aquatic hyphomycetes in such environments tends to be lower than in the running waters of the main river channel (Chergui and Pattee, 1988) with communities often dominated by very few species, such as An. longissima in a pond along the Garonne River (Baldy et al., 2002).

Recent investigations show that aquatic hyphomycetes are regular inhabitants of lakes and reservoirs, including eutrophic ones (Wurzbacher et al., 2010; Pietryczuk et al., 2014). As filamentous fungi, they require a solid substratum and, unlike yeasts and parasites of living organisms, are not common in the pelagic zone of lakes. Similarly, they have not been reported from the deep zone of lakes and their sediment which may serve as a bank of propagules for other fungi associated with deposited plant matter (Wurzbacher et al.,
2011). In contrast, the littoral zone of lakes, being sometimes subject to substantial leaf litter inputs from the terrestrial vegetation, provides potential niches for aquatic hyphomycetes as litter colonizers and decomposers as long as the abiotic conditions (e.g., oxygen availability, due to wave action) are favourable (Wurzbacher et al., 2010).

Aquatic hyphomycetes have thin-walled conidia and mycelia, which makes them vulnerable to potentially fatal desiccation (Bärlocher, 2009). Stream intermittency may, therefore, present a serious challenge for their survival. Several studies have shown that they may endure litter emersion periods of days to months and even drying-rewetting cycles as long as recolonization and/or resumption of growth is allowed by litter resubmergence in the stream (Maamri et al., 1998, 2001; Bärlocher, 2009; Bruder et al., 2011; Schlief and Mutz, 2011). Based on their conidial production, some aquatic hyphomycete species are reported to be less sensitive than others to flow fragmentation and resumption (Schlief and Mutz, 2011). Storm events result in relatively rapid changes between terrestrial and aquatic habitats in a catchment area, but change can also occur more gradually due to extended periods of little or no precipitation. This can lead to standing pools, where oxygen concentrations decline and leaf leachate concentrations and temperature increase. The first two changes lower fungal biomass and leaf decomposition rates, the third may have the opposite effect (Canhoto et al., 2013 , 2016). Thus, aquatic hyphomycetes on terrestrially stranded leaves may have had to survive both an initial aquatic phase with declining oxygen supply and the subsequent dry phase. A drying pool with a rich supply of organic detritus often has high levels of sulphide (Field and Webster, 1985), another potential stressor. Four strains of aquatic hyphomycetes were more susceptible to sulphide exposure than aero-aquatic fungi.

Due to their apparent affinity for fresh, clean and oligotrophic waters such as pristine streams, aquatic hyphomycetes could be expected to be poorly represented in polluted or chemically altered rivers. In fact, several species appear to have developed some tolerance or adaptation to contaminants (Sridhar et al., 2008; Ferreira et al., 2014). Although surviving in environments containing high amounts of organic matter, nutrients and pollutants like heavy metals, the sensitivity of aquatic hyphomycetes seems to be variable among species, which led Solé et al. (2008) to propose them as bioindicators for assessing the impact of anthropogenic stresses.

\section{Groundwater and hyporheic habitat}

In streams with porous bed materials, water is exchanged between surface and subsurface water masses (Bärlocher et al., 2006). Depending on the structure and porosity of the sedimentary matrix (e.g., variability of pore sizes in the three dimensions of the hyporheic zone; Zilliox, 1994), such water movements result in complex fluid distribution patterns (Williams and Hogg, 1988; Findlay, 1995). Stream water enters the hyporheic habitat through downwelling zones (Whitman and Clark, 1984; White et al., 1987) and returns to the streambed surface (i.e., benthic habitat) through upwelling 
zones or can penetrate deep into the ground water of alluvial aquifers (Harvey and Bencala, 1993; Valett et al., 1996; Wroblicky et al., 1998; Crenshaw et al., 2002). A substantial portion of leaf litter entering running waters is subject to burial in the streambed as a consequence of flood events (Herbst, 1980) and sediment movement (Metzler and Smock, 1990; Naegeli et al., 1995). Coarse particulate organic matter in the hyporheic zone (mostly in the form of plant detritus) can account for up to $90 \%$ of total in-stream stored organic matter (Metzler and Smock, 1990; Cornut et al., 2012b). The hyporheic habitat thus represents another potential niche for aquatic hyphomycetes.

The physical and chemical constraints prevailing in the hyporheic zone are likely to limit the fungal conditioning of leaves compared to that occurring in surface waters (Metzler and Smock, 1990; Essafi et al., 1994). This is generally supported by experimental studies, although the variety of methodologies for detecting fungal presence and/or quantifying their biomass and activity have led to somewhat contradictory results, precluding any generalization. For instance, Rounick and Winterbourn (1983) and Eichem et al. (1993) in an instream study and in situ experiment where microcosms were fed by groundwater springs, respectively, did not differentiate between bacterial and fungal activity on decomposing leaves. Naamane et al. (1999) did not find sporulating aquatic hyphomycete species associated with poplar leaves buried in the sediments (i.e., 30 and $50 \mathrm{~cm}$ below the water-sediment interface) of a Moroccan stream, while at least three species were found on leaves exposed at the sediment surface. In contrast, sterile alder leaves incubated in 13 polluted groundwater wells accumulated an unexpectedly substantial diversity of these fungi (Krauss et al., 2003). Whether such contrasting findings could have been related to particular conditions (e.g., sediment clogging, water residence time) is unknown. By relying on consistent methodologies, a lower fungal biomass associated with plant matter decomposing in the hyporheic habitat of mountainous streams compared to its benthic counterpart has, however, been documented for both leaf litter and woody debris (Cornut et al., 2010; Crenshaw et al., 2002).

While a number of studies have reported the presence of fungal hyphae in hyporheic habitats or aquifers (Sinclair and Ghiorse, 1989; Madsen et al., 1991; Madsen and Ghiorse, 1993; Ellis et al., 1998), Bärlocher and Murdoch (1989) were the first to document the occurrence of aquatic hyphomycete conidia by using glass beads buried in the sediment of a softwater stream in New Brunswick, Canada. More recently, Bärlocher et al. $(2006,2008)$ found that the occurrence of aquatic hyphomycetes in streambed sediment was closely linked to that of vascular plant detritus and suggested that aquatic hyphomycetes readily disperse within the hyporheic zone. The study by Sudheep and Sridhar (2012) revealed 23 aquatic hyphomycete species associated with coarse and fine particulate organic matter in the hyporheic zone of freshwater systems of the Western Ghats, Southwest India.

The lower dissolved oxygen concentrations prevailing in the hyporheic zone may explain the reduced leaf-associated fungal biomass and sporulation rate, as shown in the laboratory (Medeiros et al., 2009). Under hypoxic stress (i.e., $54 \%$ of $\mathrm{O}_{2}$ saturation), the fungal community evenness was substantially lowered, with Flagellospora curvula becoming dominant (Medeiros et al., 2009). In the field, the composition and structure of aquatic hyphomycete assemblages (evaluated by spore production) were also strongly affected by burial in the sediment, which suggests a superior ability of some aquatic hyphomycetes, e.g. H. lugdunensis and Ar. tetracladia, to cope with the physical and chemical conditions prevailing in the hyporheic zone (Cornut et al., 2010). To what extent and through which mechanisms these species respond differently to depletion of oxygen concentrations is currently unknown. Although it is difficult to assess the effects of dissolved oxygen concentrations on the structure of fungal communities in streams due to confounding factors (e.g., nutrient availability), several studies have underlined the potential significance of oxygen availability on fungal diversity (Chergui and Pattee, 1988; Pascoal et al., 2003; Rajashekhar and Kaveriappa, 2003; Pascoal and Cássio, 2004). These results confirm conclusions by Field and Webster (1983) that the maintenance of fungal functions under hypoxic conditions in streams is due to a few species adapted to growth under low oxygen concentrations. As a group, aero-aquatic fungi are better able to tolerate them than aquatic hyphomycetes.

Paradoxically, despite their reduced presence, the contribution of aquatic hyphomycetes to leaf litter decomposition in the hyporheic zone of streams may exceed that in the benthic habitat. Due to depressed activity of detritivorous invertebrates, mycelial and conidial production in the hyporheic environment accounted for $12 \%$ of the initial leaf carbon transformed after 80 d, i.e., roughly 3 times more than under benthic conditions, implying a major role played by these fungi in the hyporheic zone of streams (Cornut et al., 2010).

The relatively large, complex and distinctly shaped (e.g., tetraradiate, variously branched, sigmoid, or globulous) conidia of aquatic hyphomycetes, which facilitate their dispersal and attachment to submerged substrata in lotic habitats (Gulis et al., 2009; Webster, 1987) may reduce their motility in the hyporheic environment. Conidia are relatively fragile and quickly lose their ability to germinate, even under benign conditions (Sridhar and Bärlocher, 1994). Because the circulation of spores in the hyporheic zone is affected by multiple challenges associated with this sedimentary habitat (i.e., physical and physiological filtering), they are unlikely to survive long distance dispersal, in particular within the sedimentary matrix where complex water movement and fluid distribution patterns occur. From the very few studies available, the hyporheic habitat indeed seems to be impoverished with regards to aquatic hyphomycete diversity.

Manipulating sediment grain size and hyphomycete spore assemblages in laboratory mesocosms, Cornut et al. (2014) showed the importance of sediment porosity, as well as spore shape, in determining the fungal dispersal ability within streambed sediments. Significant differences occurred among aquatic hyphomycetes, with much greater dispersal efficiency of filiform spores (e.g., F. curvula) than of compact or branched/tetraradiate spores (e.g., Tricladium chaetocladium). The main factor determining dispersal ability appeared to be the spore size, i.e., span, expressed in terms of minimal obstruction size, thus inducing a strong screening among species. Interspecific interactions among spores could also affect dispersal. Sediment porosity (in relation to spore size) is crucial. For instance, spore flux was reduced by one order of 
magnitude between $4-8 \mathrm{~mm}$ and $1-2 \mathrm{~mm}$ grain size fractions (Cornut et al., 2014).

Fungal community structure and composition were consistently affected in laboratory and field conditions suggesting that physical screening of spores interacting with other factors (e.g., reduced oxygen concentration and water turbulence) is involved in the control of fungal diversity. In addition, a transplant experiment where alder leaves were subject to three alternative treatments within the streambed (i.e. buried in the sediment after 2 weeks of exposure at the sediment surface, buried in the sediment or exposed at the sediment surface throughout the experiment) showed the stimulation of conidial production, possibly reflecting mycelial development, of some aquatic hyphomycete species under hyporheic conditions (Cornut et al., 2010). All this may impact ecosystem functioning through the alteration of fungal enzymatic capacities, litter conditioning and decomposing performance (Cornut et al., 2010, 2012a; Danger et al., 2012). Finally, a substantial portion of the fungal biomass associated with decaying substrata in stream sediment may not belong to species that dominate spore production (Bärlocher et al., 2006). Clearly, documentation of all taxa, sporulating or sterile, by molecular techniques is essential (Nikolcheva and Bärlocher, 2004; Duarte et al., 2015).

\section{Approaches and tools to detect aquatic hyphomycetes}

Researchers scanning terrestrial plant material for aquatic hyphomycetes have largely relied on traditional methods developed to detect these fungi in streams (Descals, 1997). This includes submerging detritus in distilled water for direct microscopic observation of conidia or conidiophores (e.g., Webster, 1977). Detached conidia can be concentrated by floatation (Bandoni, 1972, 1974, 1981; Sridhar and Bärlocher, 1993). It is generally unknown how many of these conidia are viable.

Extended immersion of plant litter in agitated water often stimulates the formation and release of conidia, which can be counted and identified. This records fungi that are potentially reproductive. Sudheep and Sridhar (2010) introduced an intermediate step by incubating sediment with sterile leaves that were subsequently checked for the presence of aquatic hyphomycetes. This potentially captures fungi that are unable to reproduce before additional growth (Sridhar et al., 2008).

Endophytes are generally isolated into pure cultures by surface sterilizing living leaves, needles, twigs or roots. Potential adaptation to aquatic habitats can then be tested by inducing sporulation in turbulent water (Sokolski et al., 2006).

As discussed in Bärlocher (2016), these traditional methods rarely give a complete picture of the fungal diversity in any habitat, nor do they reveal the participation of recorded taxa in ecological processes. For more complete assessments, molecular methods are indispensable. Next generation sequencing potentially allows capturing all members of a community. Simultaneously targeting the fungal precursor rRNA pool identifies metabolically active taxa. Potential contributions to decomposition processes by various fungal taxa can be assessed by functional markers (Bärlocher, 2016).
Together, they reveal which species are there, which species are active, and how individual members of the community might participate in decomposition processes. Such information will shed light on the distribution of individual taxa or broad ecological groups, such as aquatic hyphomycetes or canopy fungi and their participation in ecological processes. Haplotype analysis might reveal mutual exchanges between different habitats (e.g., between a stream and adjacent soils and forests) and the impact of sexually produced propagules. Despite molecular advances, however, careful observations on field-collected material collected or on pure cultures can still provide valuable clues to conditions that may be acceptable to a species. For example, Ar. tetracladia, which is common on leaves decaying in streams and has often been reported from terrestrial and semi-aquatic habitats, has two spore shapes. The angulata form is more common at terrestrial and the tetracladia form dominates at aquatic sites (Sridhar and Bärlocher, 1993). Another species with an apparently flexible strategy is Spirosphaera dimorpha (Marvanová and Bärlocher, 1998). One morph bears air-trapping propagules (typical for aero-aquatic fungi), and another produces the stauroconidial Lambosporidium (typical in aquatic hyphomycetes).

\section{Conclusions}

The present review highlights the ecological versatility of aquatic hyphomycetes, which are a phylogenetically heterogenous group of fungi. Their occurrence outside of streams has been documented quite early, with regular reports originating from a very wide variety of environments either aquatic (e.g., slow-flowing and standing waters, estuaries, and hyporheic zone) or terrestrial (several tree compartments and forest floor), thus more or less adjacent to their typical habitat. There is some evidence that their terrestrial existence may be more common than suspected. Clearly, studies on aquatic hyphomycetes now have to fully enter the genomic era: a main goal is to understand how their genomes allow colonization of multiple, and sometimes unexpectedly divergent, niches; a second one, relying on transcriptomics and proteomics, is to investigate how differential expression of their genomic abilities adapt them to these niches and their constrains. Concerning the ability of some aquatic hyphomycetes to live as plant endophytes, a crucial question refers to the way and form through which they escape the aquatic systems to re-colonize plants. Finally, future investigations should aim at determining how their presence outside streams contributes to the functioning of aquatic (and non-aquatic) ecosystems. Their occurrence as endophytes but not saprotrophs in terrestrial ecosystems could suggest a marginal role in the regulation of organic carbon and nutrients, in contrast with their eminent role in the detrital food chain and importance in the functioning of woodland stream ecosystems (Suberkropp, 1997). Niche duality and contribution of surrounding environments as reservoirs of propagules may however be crucial, with such a pathway perhaps occurring more regularly than only during extreme events. The functional role of outsidestream niches for aquatic hyphomycetes remains to be characterized and quantified, and future research might provide ecological surprises. 


\section{Acknowledgements}

We are grateful to Lynne Boddy and an anonymous reviewer whose comments improved our manuscript.

\section{R E F E R E N C E S}

Abadie, J., Püttsepp, U., Gebauer, G., Faccio, A., Bonfante, P., Selosse, M.-A., 2006. Cephalanthera longifolia (Neottieae, Orchidaceae) is mixotrophic: a comparative study between green and non-photosynthetic individuals. Canadian Journal of Botany 84, 1462-1477.

Ando, K., 1992. A study of terrestrial aquatic hyphomycetes. Transactions of the Mycological Society of Japan 33, 415-425.

Ando, K., Kawamoto, I., 1986. Arborispora, a new genus of hyphomycetes. Transactions of the Mycological Society of Japan 27, 119-128.

Ando, K., Tubaki, K., 1984a. Some undescribed hyphomycetes in the rain drops from intact leaf-surface. Transactions of the Mycological Society of Japan 25, 21-37.

Ando, K., Tubaki, K., 1984b. Some undescribed hyphomycetes in the rain water draining from intact trees. Transactions of the Mycological Society of Japan 25, 39-47.

Baldy, V., Chauvet, E., Charcosset, J.-Y., Gessner, M.O., 2002. Microbial dynamics associated with leaves decomposing in the mainstem and floodplain pond of a large river. Aquatic Microbial Ecology 28, 25-36. http://dx.doi.org/10.3354/ame028025.

Bandoni, R.J., 1972. Terrestrial occurrence of some aquatic hyphomycetes. Canadian Journal of Botany 50, 2283-2288.

Bandoni, R.J., 1974. Mycological observations on the aqueous films covering decaying leaves and other litter. Transactions of the Mycological Society of Japan 15, 309-315.

Bandoni, R.J., 1981. Aquatic hyphomycetes from terrestrial litter. In: Wicklow, D.T., Carroll, G.C. (Eds.), The Fungal Community. Its Organization and Role in the Ecosystem. Marcel Dekker, New York, pp. 693-708.

Bandoni, R.J., Koske, R.E., 1974. Monolayers and microbial dispersal. Science 183, 1079-1081.

Bärlocher, F., 1981. Fungi on the food and in the faeces of Gammarus pulex. Transactions of the British Mycological Society 76 160-165.

Bärlocher, F., 1992a. Research on aquatic hyphomycetes: historical background and overview. In: Bärlocher, F. (Ed.), The Ecology of Aquatic Hyphomycetes. Springer-Verlag, Berlin, Germany, pp. 1-15.

Bärlocher, F., 1992b. Recent developments in stream ecology and their relevance to aquatic mycology. In: Bärlocher, F. (Ed.), The Ecology of Aquatic Hyphomycetes. Springer-Verlag, Berlin, Germany, pp. 16-37.

Bärlocher, F., 2006. Fungal endophytes in submerged roots. In: Schulz, B.J.Z., Boyle, C.J.C., Sieber, T.N. (Eds.), Microbial Roots Endophytes. Springer Verlag, Berlin, Germany, pp. 179-190.

Bärlocher, F., 2009. Reproduction and dispersal in aquatic hyphomycetes. Mycoscience 50, 3-8. http://dx.doi.org/10.1007/ S10267-008-0449-X.

Bärlocher, F., 2016. Aquatic hyphomycetes in a changing environment. Fungal Ecology 19, 14-27.

Bärlocher, F., Murdoch, J., 1989. Hyporheic biofilms-a potential food source for hyporheic animals. Hydrobiologia 184, 61-67.

Bärlocher, F., Nikolcheva, L.G., Wilson, K.P., Williams, D.D., 2006. Fungi in the hyporheic zone of a springbrook. Microbial Ecology 52, 708-715. http://dx.doi.org/10.1007/s00248-006-9102-4.

Bärlocher, F., Seena, S., Wilson, K., Williams, D., 2008. Raised water temperature lowers diversity of hyporheic aquatic hyphomycetes. Freshwater Biology 53, 368-379.
Behie, S.W., Zelisko, P.M., Bidochka, M.J., 2012. Endophytic insectparasitic fungi translocate nitrogen directly from insects to plants. Science 336, 1576-1577.

Bessey, E.A., 1939. Varicosporium elodeae Kegel, an uncommon soil fungus. Papers of the Michigan Academy of Science, Arts and Letters 35, 15-17.

Brouard, O., Céréghino, R., Corbara, B., Leroy, C., Pelozuelo, L., Dejean, A., Carrias, J.-F., 2012. Understorey environments influence functional diversity intank-bromeliad ecosystems. Freshwater Biology 57, 815-823.

Bruder, A., Chauvet, E., Gessner, M.O., 2011. Litter diversity, fungal decomposers and litter decomposition under simulated stream intermittency. Functional Ecology 25, 1269-1277. http:// dx.doi.org/10.1111/j.1365-2435.2011.01903.x.

Canhoto, C., Calapez, R., Gonçalves, A.L., Moreira-Santos, M., 2013. Effects of Eucalyptus leachates and oxygen on leaf-litter processing by fungi and stream invertebrates. Freshwater Science 32, 411-424.

Canhoto, C., Gonçalves, A., Bärlocher, F., 2016. Ecology of aquatic hyphomycetes in a warming climate. Fungal Ecology 19, 201-218.

Carroll, G.C., 1981. Mycological inputs to ecosystems analysis. In: Wicklow, D.T., Carroll, G.C. (Eds.), The Fungal Community: Its Organization and Role in the Ecosystem. Marcel Dekker, New York, pp. 25-35.

Chergui, H., Pattee, E., 1988. The dynamics of hyphomycetes on decaying leaves in the network of the River Rhône (France). Archiv für Hydrobiologie 114, 3-20.

Cornut, J., Chauvet, E., Mermillod-Blondin, F., Assemat, F., Elger, A., 2014. Aquatic hyphomycete species are screened by the hyporheic zone of woodland streams. Applied and Environmental Microbiology 80, 1949-1960. http://dx.doi.org/ 10.1128/AEM.03024-13.

Cornut, J., Clivot, H., Chauvet, E., Elger, A., Pagnout, C., Guérold, F., 2012a. Effect of acidification on leaf litter decomposition in benthic and hyporheic zones of woodland streams. Water Research 46, 6430-6444. http://dx.doi.org/10.1016/ j.watres.2012.09.023.

Cornut, J., Elger, A., Greugny, A., Bonnet, M., Chauvet, E., $2012 b$. Coarse particulate organic matter in the interstitial zone of three French headwater streams. Annales de Limnologie International Journal of Limnology 48, 303-313. http://dx.doi.org/ 10.1051/limn/2012019.

Cornut, J., Elger, A., Lambrigot, D., Marmonier, P., Chauvet, E., 2010. Early stages of leaf decomposition are mediated by aquatic fungi in the hyporheic zone of woodland streams. Freshwater Biology 55, 2541-2556. http://dx.doi.org/10.1111/ j.1365-2427.2010.02483.x.

Crenshaw, C., Valett, H., Tank, J., 2002. Effects of coarse particulate organic matter on fungal biomass and invertebrate density in the subsurface of a headwater stream. Journal of the North American Benthological Society 21, 28-42.

Czeczuga, B., Orłowska, M., 1994. Some aquatic fungi of hyphomycetes on tree leaves. Roczniki Akademii Medycznej w Bialymstoku 39, 86-92.

Czeczuga, B., Orłowska, M., 1998a. Hyphomycetes in rain water draining from intact trees. Roczniki Akademii Medycznej w Bialymstoku 43, 66-84.

Czeczuga, B., Orłowska, M., 1998b. Hyphomycetes in the snow from gymnosperm trees. Roczniki Akademii Medycznej w Bialymstoku 43, 85-94.

Czeczuga, B., Orłowska, M., 1999. Hyphomycetes in rainwater, melting snow and ice. Acta Mycologica 34, 181-200.

Dang, C.K., Gessner, M.O., Chauvet, E., 2007. Influence of conidial traits and leaf structure on attachment success of aquatic hyphomycetes on leaf litter. Mycologia 99, 24-32.

Danger, M., Cornut, J., Elger, A., Chauvet, E., 2012. Effects of burial on leaf litter quality, microbial conditioning and palatability to 
three shredder taxa. Freshwater Biology 57, 1017-1030. http:// dx.doi.org/10.1111/j.1365-2427.2012.02762.x.

Davey, M., Blaalid, R., Vik, U., Carlsen, T., Kauserud, H., Bronken Eidesen, P., 2015. Primary succession of Bistorta vivipara (L.) Delabre (Polygonaceae) root-associated fungi mirrors plant succession in two glacial chronosequences. Environmental Microbiology. http://dx.doi.org/10.1111/1462-2920.12770 (in press).

Davis, E., Franklin, J., Shaw, J., Vilgalys, R., 2003. Endophytic Xylaria (Xylariaceae) among liverworts and angiosperms:

phylogenetics, distribution and symbiosis. American Journal of Botany 90, 1661-1667.

Descals, E., 1997. Ingoldian fungi: some field and laboratory techniques. Bolletin de la Societat d'Historia Natural de les Balears 40, 169-221.

Descals, E., Moralejo, E., 2010. Water and asexual reproduction in the ingoldian fungi. Botanica complutensis 25, 13-71.

Duarte, S., Bärlocher, F., Trabulo, J., Cássio, F., Pascoal, C., 2015. Stream-dwelling fungal decomposer communities along a gradient of eutrophication unraveled by 454 pyrosequencing. Fungal Diversity 70, 127-148.

Dyko, B.J., 1976. A preliminary study of aquatic hyphomycetes on leaves in forest and stream leaf litter. Journal of the Tennessee Academy of Science 51, 7-8.

Eichem, A., Dodds, W., Tate, C., Edler, C., 1993. Microbial decomposition of elm and oak leaves in a karst aquifer. Applied and Environmental Microbiology 59, 3592-3596.

Elena, V., Gastaldo, A., Tondello, A., Baldan, B., Villani, M., Squartini, A., 2010. Identification of two fungal endophytes associated with the endangered orchid Orchis militaris L. Journal of Microbiology and Biotechnology 20, 630-636.

Ellis, B., Stanford, J., Ward, J., 1998. Microbial assemblages and production in alluvial aquifers of the flathead river, Montana, USA. Journal of the North American Benthological Society 17, 382-402.

Essafi, K., Chergui, H., Pattee, E., Mathieu, J., 1994. The breakdown of dead leaves buried in the sediment of a permanent stream in Morocco. Archiv für Hydrobiologie 130, 105-112.

Fabre, E., 1998. Aquatic hyphomycetes in three rivers of southwestern France. I. Spatial and temporal changes in conidial concentration, species richness, and community diversity. Canadian Journal of Botany 76, 99-106.

Ferreira, V., Gulis, V., Pascoal, C., Graça, M.A.S., 2014. Stream pollution and fungi. In: Jones, E., Hyde, K., Pang, K.-L. (Eds.), Freshwater Fungi and Fungal-like Organisms. De Gruyter, Riyadh, Saudi Arabia, pp. 389-412.

Field, J.I., Webster, J., 1983. Anaerobic survival of aquatic fungi. Transactions of the British Mycological Society 81, 365-369. http:// dx.doi.org/10.1016/S0007-1536(83)80088-6.

Field, J.I., Webster, J., 1985. Effects of sulphide on survival of aeroaquatic and aquatic hyphomycetes. Transactions of the British Mycological Society 85, 193-199.

Findlay, S.E.G., 1995. Importance of surface-subsurface exchange in stream ecosystems: the hyporheic zone. Limnology and Oceanography 40, 159-164.

Fisher, P., Petrini, O., 1990. Two aquatic hyphomycetes as endophytes in Alnus glutinosa roots. Transactions of the British Mycological Society 81, 523-527.

Fuentes-Cid, A., Chauvet, E., Etcheber, H., De-Oliveira, E., Sottolichio, A., Schmidt, S., 2015. Leaf litter degradation in highly turbid transitional waters: preliminary results from litter-bag experiments in the Gironde Estuary. Geodinamica Acta 27, 60-66. http://dx.doi.org/10.1080/ 09853111.2013.877233.

Gönczöl, J., 1976. Ecological observations on the aquatic hyphomycetes of Hungary II. Acta Botanica Academiae Scientiarum Hungaricae 22, 51-60.

Gönczöl, J., Révay, Á., 1983. Observations on the hyphomycetes inhabiting forest litter of Hungary. Acta Botanica Hungarica 29, $107-125$.
Gönczöl, J., Révay, Á., 1996. A new Colispora (hyphomycetes) from tree hollows. Mycotaxon 59, 237-244.

Gönczöl, J., Révay, Á., 2003. Treehole fungal communities: aquatic, aero-aquatic and dematiaceous hyphomycetes. Fungal Diversity 12, 19-34.

Gönczöl, J., Révay, Á., 2004. Fungal spores in rainwater: stemflow, throughfall and gutter conidial assemblages. Fungal Diversity $16,67-86$.

Gönczöl, J., Révay, Á., 2006. Species diversity in rainborne hyphomycete conidia from living trees. Fungal Diversity 22, $37-54$.

Goos, R.D., 1978. Occurrence of Triscelophorus monosporus in upland sites on Oahu, Hawaii. Mycologia 70, 188-189.

Gregory, P.H., Hirst, J.M., 1957. The summer air-spora at Rothamsted in 1952. Journal of General Microbiology 17, 135-152.

Gulis, V., Kuehn, K., Suberkropp, K., 2009. Fungi. In: Likens, G. (Ed.), Encyclopedia of Inland Waters. Elsevier, Oxford, United Kingdom, pp. 233-243.

Hammond, P., Stork, N., Brendell, M., 1977. Tree crown beetles in context: a comparison of canopy and other ecotone assemblages in a lowland tropical forest in Sulawesi. In: Stork, N., Adis, J., Didham, R. (Eds.), Canopy Arthropods. Chapman and Hall, London, pp. 184-223.

Hartig, R., 1880. Der Ahornkeimlingspilz, Cercospora acerina m, vol. 1. Untersuchungen aus dem Forstbotanischen Inst, zu München, pp. 58-61.

Harvey, J., Bencala, K., 1993. The effect of streambed topography on surface-subsurface water exchange in mountain catchments. Water Resources Research 29, 89-98.

Herbst, G.N., 1980. Effects of burial on food value and consumption of leaf detritus by aquatic invertebrates in a Lowland Forest stream. Oikos 35, 411-424. http://dx.doi.org/ $10.2307 / 3544658$

Hudson, H.J., Sutton, B.C., 1964. Trisulcosporium and Tetranacrium, two new genera of Fungi imperfecti. Transactions of the British Mycological Society 47, 197-203.

Ingold, C.T., 1942. Aquatic hyphomycetes on decaying alder leaves. Transactions of the British Mycological Society 25, 339-417.

Ingold, C.T., 1975. Guide to Aquatic and Water-borne Hyphomycetes (Fungi imperfecti) with Notes on Their Biology. Scientific Publication No. 30.

Iqbal, S.H., Webster, J., 1969. Pathogenicity of aquatic isolates of Centrospora acerina to carrots and parsnips. Transactions of the British Mycological Society 53, 486-490.

Kalenitchenko, D., Fagervold, S., Pruski, A., Vétion, G., Yücel, M., Le Bris, N., Galand, P., 2015. Temporal and spatial constraints on community assembly during microbial colonisation of wood in seawater. ISME Journal. http://dx.doi.org/10.1038/ ismej.2015.61 (in press).

Karamchand, K.S., Sridhar, K.R., 2008. Water-borne conidial fungi inhabiting tree holes of the west coast and Western Ghats of India. Czech Mycology 60, 63-74.

Karamchand, K.S., Sridhar, K.R., 2009. Association of water-borne conidial fungi with epiphytic tree fern (Drynaria quercifolia). Acta Mycologica 44, 19-27.

Kaufman, M.G., Chen, S., Walker, E.D., 2008. Leaf-associated bacterial and fungal taxa shifts in response to larvae of the tree hole mosquito, Ochlerotatus triseriatus. Microbial Ecology 55, 673-684. http://dx.doi.org/10.1007/s00248-007-9310-6.

Kearns, S., Barlocher, F., 2008. Leaf surface roughness influences colonization success of aquatic hyphomycete conidia. Fungal Ecology 1, 13-18. http://dx.doi.org/10.1016/ j.funeco.2007.07.001.

Kegel, W., 1906. Varicosporium elodeae, ein Wasserpilz mit auffallender Konidienbildung. Berichte der Deutschen Botanischen Gesellschaft 68, 465-515.

Khan, M.A., 1986. Survival of aquatic hyphomycetes under dry conditions. Pakistan Journal of Botany 18, 335-339. 
Kirby, J.J.H., Webster, J., Baker, J.H., 1990. A particle plating method for analysis of fungal community composition and structure. Mycological Research 94, 621-626. http://dx.doi.org/ 10.1016/S0953-7562(09)80663-1.

Kitching, R.L., 1971. An ecological study of water-filled treeholes and their position in the woodland ecosystem. Journal of Animal Ecology 40, 281-302.

Kohler, A., Kuo, A., Nagy, L., Morin, E., Barry, K., Buscot, F., Canbäck, B., Choi, C., Cichocki, N., Clum, A., 2015. Convergent losses of decay mechanisms and rapid turnover of symbiosis genes in mycorrhizal mutualists. Nature Genetics 47, 410-415.

Koske, R.E., Duncan, I.W., 1974. Temperature effects on growth, sporulation, and germination of some "aquatic" hyphomycetes. Canadian Journal of Botany 52, 1387-1391.

Krauss, G., Sridhar, K., Jung, K., Wennrich, R., Ehrman, J., Bärlocher, F., 2003. Aquatic hyphomycetes in polluted groundwater habitats of Central Germany. Microbial Ecology 45, 329-339.

Lackey, J.B., 1940. The microscopic flora and fauna of tree holes. Ohio Journal of Science 40, 186-192.

Langhans, S.D., Tiegs, S.D., Gessner, M.O., Tockner, K., 2008. Leafdecomposition heterogeneity across a riverine floodplain mosaic. Aquatic Science 70, 337-346.

Langhans, S.D., Tockner, K., 2006. The role of timing, duration, and frequency of inundation in controlling leaf litter decomposition in a river-floodplain ecosystem (Tagliamento, northeastern Italy). Oecologia 147, 501-509. http://dx.doi.org/ 10.1007/s00442-005-0282-2.

Leberfinger, K., Bohman, I., Herrmann, J., 2010. Drought impact on stream detritivores: experimental effects on leaf litter breakdown and life cycles. Hydrobiologia 652, 247-254.

Lutscher, F., McCauley, E.D., Lewis, M.A., 2007. Spatial patterns and coexistence mechanisms in systems with unidirectional flow. Theoretical Population Biology 71, 267-277.

Maamri, A., Bärlocher, F., Pattee, E., Chergui, H., 2001. Fungal and bacterial colonisation of Salix pedicellata leaves decaying in permanent and intermittent streams in Eastern Morocco. International Review of Hydrobiology 86, 337-348.

Maamri, A., Chauvet, E., Chergui, H., Gourbière, F., Pattee, E., 1998. Microbial dynamics on decaying leaves in a temporary Moroccan river. I - Fungi. Archiv für Hydrobiologie 144, 41-59.

Maamri, A., Chauvet, E., Pattee, E., 2006. Décomposition des feuilles d'eucalyptus dans la basse Moulouya (Maroc oriental): impact de la salinité dans le processus. In: 8ème Conférence Internationale Des Limnologues d'Expression Française. Hammamet, Tunisia.

MacKinnon, J., 1982. Stemflow and Throughfall Mycobiota of a Trembling Aspen-red Alder Forest. (MSc thesis) University of British Columbia, Vancouver.

Madsen, E.L., Ghiorse, W.C., 1993. Groundwater microbiology: subsurface ecosystem processes. In: Ford, T. (Ed.), Aquatic Microbiology: An Ecological Approach. Blackwell, Cambridge, MA, pp. 167-213.

Madsen, E., Sinclair, J., Ghiorse, W., 1991. In situ biodegradation: microbial patterns in a contaminated aquifer. Science 252, 830-833.

Magyar, D., Gönczöl, J., Révay, Á., Grillenzoni, F., Seijo-Coello, M., 2005. Stauro- and scolecoconidia in floral and honeydew honeys. Fungal Diversity 20, 103-120.

Mäkelä, K., 1972. Some aquatic hyphomycetes on grasses in Finland. Karstenia 13, 16-22.

Marvanová, L., Bärlocher, F., 1998. Hyphomycetes from Canadian streams. IV. Spirosphaera dimorpha sp. nov. Mycotaxon 68, 33-40.

Medeiros, A.O., Pascoal, C., Graça, M.A.S., 2009. Diversity and activity of aquatic fungi under low oxygen conditions. Freshwater Biology 54, 142-149. http://dx.doi.org/10.1111/ j.1365-2427.2008.02101.x.
Metzler, G.M., Smock, L.A., 1990. Storage and dynamics of subsurface detritus in a sandbottomed stream. Canadian Journal of Fisheries and Aquatic Sciences 47, 588-594.

Michaelides, J., Kendrick, B., 1978. An investigation of factors retarding colonization of conifer needles by amphibious hyphomycetes in streams. Mycologia 70, 419-430.

Müller, K., 1982. The colonization cycle of freshwater insects. Oecologia 53, 202-207.

Murat, C., Vizzini, A., Bonfante, P., Mello, A., 2005. Morphological and molecular typing of the below-ground fungal community in a natural Tuber magnatum truffle-ground. FEMS Microbiology Letters 245, 307-313.

Naamane, B., Chergui, H., Pattee, E., 1999. The breakdown of leaves of poplar and holm oak in three Moroccan streams: effect of burial in the sediment. Annales de LimnologieInternational Journal of Limnology 35, 263-275.

Nadkarni, N., Mewin, M., Niedert, J., 2001. Forest canopies, plant diversity. Encyclopedia of Biodiversity 3, 27-40.

Naegeli, M., Hartmann, U., Meyer, E., Uehlinger, U., 1995. POMdynamics and community respiration in the sediments of a floodprone prealpine river (Necker, Switzerland). Archiv für Hydrobiologie 133, 339-347.

Nikolcheva, L., Bärlocher, F., 2004. Taxon-specific primers reveal unexpectedly high diversity during leaf decomposition in a stream. Mycological Progress 3, 41-50.

Osono, T., Mori, A., 2004. Distribution of phyllosphere fungi within the canopy of giant dogwood. Mycoscience 45, 161-168.

Ozanne, C.M.P., Anhuf, D., Boulter, S.L., Keller, M., Kitching, R.L., Körner, C., Meinzer, F.C., Mitchell, A.W., Nakashizuka, T., Silva Dias, P.L., Stork, N.E., Wright, S.J., Yoshimura, M., 2003. Biodiversity meets the atmosphere: a global view of forest canopies. Science 301, 183-186.

Pachepsky, E., Lutscher, F., Nisbet, R.M., Lewis, M.A., 2005. Persistence, spread and the drift paradox. Theoretical Population Biology 67, 61-73.

Park, D., 1972. On the ecology of heterotrophic micro-organisms in fresh-water. Transactions of the British Mycological Society 58, 291-299.

Park, D., 1974. Aquatic hyphomycetes in non-aquatic habitats. Transactions of the British Mycological Society 63, 183-187.

Pascoal, C., Cássio, F., 2004. Contribution of fungi and bacteria to leaf litter decomposition in a polluted river. Applied and Environmental Microbiology 70, 5266-5273. http://dx.doi.org/ 10.1128/AEM.70.9.5266.

Pascoal, C., Pinho, M., Cassio, F., Gomes, P., 2003. Assessing structural and functional ecosystem condition using leaf breakdown: studies on a polluted river. Freshwater Biology 48, 2033-2044. http://dx.doi.org/10.1046/j.1365-2427.2003. 01130.x.

Pietryczuk, A., Cudowski, A., Hauschild, T., 2014. Effect of Trophic Status in Lakes on Fungal Species Diversity and Abundance, vol. 109, pp. 32-37.

Porras-Alfaro, A., Bayman, P., 2011. Hidden fungi, emergent properties: endophytes and microbiomes. Annual Review of Phytopathology 49, 291-315.

Price, I.P., Talbot, P.H., 1966. An aquatic hyphomycete in a lignicolous habitat. Australian Journal of Botany 14, 19-23.

Rajashekhar, M., Kaveriappa, K., 2003. Diversity of aquatic hyphomycetes in the aquatic ecosystems of the Western Ghats of India. Hydrobiologia 501, 167-177.

Rämä, T., Nordén, J., Davey, M.L., Mathiassen, G.H., Spatafora, J.W., Kauserud, H., 2014. Fungi ahoy! Diversity on marine wooden substrata in the high North. Fungal Ecology 8, 46-58. http://dx.doi.org/10.1016/j.funeco.2013.12.002.

Ranzoni, F.V., 1956. The perfect state of Flagellospora penicillioides. American Journal of Botany 43, 13-17.

Révay, A., Gönczöl, J., 2010. Rainborne hyphomycete conidia from evergreen trees. Nova Hedwigia 91, 151-163. 
Révay, A., Gönczöl, J., 2011. Canopy fungi ("terrestrial aquatic hyphomycetes") from twigs of living evergreen and deciduous trees in Hungary. Nova Hedwigia 92, 303-316.

Rounick, J., Winterbourn, M., 1983. Leaf processing in 2 contrasting beech forest streams - effects of physical and biotic factors on litter breakdown. Archiv für Hydrobiologie 96, 448-474.

Russell, J., Bulman, S., 2005. The liverwort Marchantia foliacea forms a specialised symbiosis with AM fungi in the genus Glomus. New Phytologist 165, 567-579.

Saccardo, P.A., 1880. Conspectus generum fungorum Italiae inferiorium nempe ad Sphaeropsideas, Melanconieas et Hyphomyceteas pertinentium, systemate sporologico dispositu. Michelia 2, 1-38.

Sanders, P.F., Webster, J., 1978. Survival of aquatic hyphomycetes in terrestrial situations. Transactions of the British Mycological Society 71, 231-237.

Sati, S., Belwal, M., 2005. Aquatic hyphomycetes as endophytes of riparian plant roots. Mycologia 97, 45-49.

Schlickeisen, E., Tietjen, T.E., Arsuff, T.L., Groeger, A.W., 2003. Detritus processing and microbial dynamics of an aquatic macrophyte and terrestrial leaf in a thermally constant, spring-fed stream. Microbial Ecology 45, 411-418. http:// dx.doi.org/10.1007/s00248-002-1062-8.

Schlief, J., Mutz, M., 2011. Leaf decay processes during and after a supra-seasonal hydrological drought in a temperate Lowland stream. International Review of Hydrobiology 96, 633-655. http:// dx.doi.org/10.1002/iroh.201111322.

Scourfield, D.J., 1940. The microscopic life of the "leaf carpet" of woods and forests. Essex Naturalist 66, 231-246.

Seena, S., Monroy, S., 2016. Preliminary insights into the evolutionary relationships of aquatic hyphomycetes and endophytic fungi. Fungal Ecology 19, 128-134.

Selosse, M.-A., Vohník, M., Chauvet, E., 2008. Out of the rivers: are some aquatic hyphomycetes plant endophytes? New Phytology 178, 3-7 http://dx.doi.org/10.1111/j.1469-8137.2008.02390.x.

Sinclair, J., Ghiorse, W., 1989. Distribution of aerobic bacteria, protozoa, algae, and fungi in deep subsurface sediments. Geomicrobiology Journal 7, 15-31.

Singh, N., Musa, T.M., 1977. Terrestrial occurrence and the effect of temperature on growth, sporulation and spore germination, of some tropical aquatic hyphomycetes. Transactions of the British Mycological Society 68, 103-106.

Sokolski, S., Piché, Y., Chauvet, E., Bérubé, J.A., 2006. A fungal endophyte of black spruce (Picea mariana) needles is also an aquatic hyphomycete. Molecular Ecology 15, 1955-1962. http:// dx.doi.org/10.1111/j.1365-294X.2006.02909.x.

Solé, M., Fetzer, I., Wennrich, R., Sridhar, K.R., Harms, H., Krauss, G., 2008. Aquatic hyphomycete communities as potential bioindicators for assessing anthropogenic stress. Science of The Total Environment 389, 557-565. http://dx.doi.org/ 10.1016/j.scitotenv.2007.09.010.

Sridhar, K.R., 2009. Fungi in the tree canopy: an appraisal. In: Rai, M., Bridge, P.D. (Eds.), Applied Mycology. CAB International, Wallingford, UK, pp. 73-91.

Sridhar, K.R., Bärlocher, F., 1993. Aquatic hyphomycetes on leaf litter in and near a stream in Nova Scotia, Canada. Mycological Research 97, 1530-1535.

Sridhar, K.R., Bärlocher, F., 1994. Viability of aquatic hyphomycete conidia in foam. Canadian Journal of Botany 72, 106-110.

Sridhar, K.R., Bärlocher, F., Wennrich, R., Krauss, G.-J., Krauss, G., 2008. Fungal biomass and diversity in sediments and on leaf litter in heavy metal contaminated waters of Central Germany. Fundamental and Applied Limnology 171, 63-74.

Sridhar, K.R., Karamchand, K.S., 2009. Diversity of water-borne fungi in throughfall and stemflow of tree canopies in India. Sydowia 61, 327-344.
Sridhar, K.R., Karamchand, K.S., Bhat, R., 2006. Arboreal waterborne hyphomycetes with oak-leaf basket fern Drynaria quercifolia. Sydowia 58, 309-320.

Sridhar, K.R., Karamchand, K.S., Seena, S., 2013. Fungal assemblage and leaf litter decomposition in coastal stream and riparian tree holes of the south-west India. Mycology 4, 118-124.

Sridhar, K.R., Kaveriappa, K.M., 1987. Occurrence and survival of aquatic hyphomycetes under terrestrial conditions. Transactions of the British Mycological Society 89, 606-609.

Stark, C., Babik, W., Durka, W., 2009. Fungi from the roots of the common terrestrial orchid Gymnadenia conopsea. Mycological Research 13, 952-959.

Stewart, E., Zhao, W., Crous, P., Szabo, L., 1999. Phylogenetic relationships among some cercosporoid anamorphs of mycosphaerella based on rDNA sequence analysis. Mycological Research 103, 1491-1499.

Suberkropp, K., 1997. Annual production of leaf-decaying fungi in a woodland stream. Freshwater Biology 38, 169-178.

Suberkropp, K., Michelis, L., Lorch, H.-J., Ottow, J.C.G., 1988. Effect of sewage treatment plant effluents on the distribution of aquatic hyphomycetes in the River Erms, Schwäbische Alb. Aquatic Botany 32, 141-153.

Sudheep, N., Sridhar, K., 2012. Aquatic hyphomycetes in hyporheic freshwater habitats of southwest India. Limnologica - Ecology and Management of Inland Waters 42, 87-94.

Sudheep, N.M., Sridhar, K.R., 2010. Water-borne hyphomycetes in tree canopies of Kaiga (Western Ghats), India. Acta Mycologica 45, 185-195.

Tedersoo, L., Pellet, P., Kõljalg, U., Selosse, M.-A., 2007. Parallel evolutionary paths to mycoheterotrophy in understorey Ericaceae and Orchidaceae: ecological evidence for mixotrophy in Pyroleae. Oecologia 151, 206-217.

Thakur, S.B., 1977. Survival of some aquatic hyphomycetes under dry conditions. Mycologia 69, 843-845.

Tubaki, K., Tokumasu, S., Anclo, K., 1985. Morning dew and Tripospermum (Hyphomycetes). Botanical Journal of the Linnean Society $91,45-50$.

Unterseher, M., Otto, P., Morawetz, W., 2005. Species richness and substrate specificity of lignicolous fungi in the canopy of a temperate, mixed deciduous forest. Mycol Progress 4, 117-132.

Valett, H., Morrice, J., Dahm, C., Campana, M., 1996. Parent lithology surface groundwater exchange, and nitrate retention in headwater streams. Limnology and Oceanography 41, 333-345.

Vannote, R., Minshall, G., Cummins, K., Sedell, J., Cushing, C., 1980. The river Continuum concept. Canadian Journal of Fisheries and Aquatic Science 37, 130-137.

Vohník, M., Mrnka, L., Lukesova, T., Bruzone, M.C., Kohout, P., Fehrer, J., 2013. The cultivable endophytic community of Norway spruce, ectomycorrhizas from microhabitats lacking ericaceous hosts is dominated by ericoid mycorrhizal Meliniomyces variabilis. Fungal Ecology 6, 281-292.

Waid, J., 1954. Occurrence of aquatic hyphomycetes upon the root surfaces of beech grown in woodland soils. Transactions of the British Mycological Society 37, 420-421.

Webster, J., 1977. Seasonal observations on "aquatic" hyphomycetes on oak leaves on the ground. Transactions of the British Mycological Society 68, 108-111.

Webster, J., 1987. Convergent evolution and the functional significance of spore shape in aquatic and semi-aquatic fungi. In: Rayner, A., Brasier, C., Moore, D. (Eds.), Evolutionary Biology of the Fungi. Cambridge University Press, Cambridge, pp. 191-201.

Webster, J., 1992. Anamorph-teleomorph relationships. In: Bärlocher, F. (Ed.), The Ecology of Aquatic Hyphomycetes. Springer-Verlag, Berlin, Germany, pp. 99-117. 
Wedin, M., Döring, H., Gilenstam, G., 2004. Saprotrophy and lichenization as options for the same fungal species on different substrata: environmental plasticity and fungal lifestyles in the Stictis-Conotrema complex. New Phytologist 164 459-465.

Weiss, F., Waller, A., Uccaro, A., Selosse, M.-A., 2015. One thousand and one interactions: the kamasutra of plant-Sebacinales liaisons (Tansley Review). New Phytologist (in press).

White, D., Elzingaa, C., Hendricks, S., 1987. Temperature patterns within the hyporheic zone of a northern Michigan river. Journal of the North American Benthological Society 6, 85-91.

Whitman, R., Clark, W., 1984. Availability of dissolved oxygen in interstitial waters of a sandy creek. Hydrobiologia 92, 651-658.

Williams, D., Hogg, J., 1988. Ecology and production of invertebrates in a Canadian coldwater spring-springbrook system. Holarctic Ecology 11, 41-54.

Wilson, D., 1995. Endophyte: the evolution of a term, and clarification of its use and definition. Oikos 73, 274-276.

Wroblicky, G., Campana, M., Valett, H., Dahm, C., 1998. Seasonal variation in surface-subsurface water exchange and the lateral hyporheic area of two stream-aquifer systems. Water Resources Research 34, 317-328.

Wurzbacher, C., Bärlocher, F., Grossart, H.-P., 2010. Fungi in lake ecosystems. Aquatic Microbial Ecology 59, 125-149. http:// dx.doi.org/10.3354/ame01385.

Wurzbacher, C., Kerr, J., Grossart, H.-P., 2011. Aquatic fungi. In: Grillo, O., Venora, G. (Eds.), The Dynamical Processes of Biodiversity - Case Studies of Evolution and Spatial Distribution. InTech, Rijeka, Croatia, pp. 227-258. http:// dx.doi.org/10.5772/23029.

Zilliox, L., 1994. Porous media and aquifer systems. In: Gibert, J., Danielopol, D., Stanford, J. (Eds.), Groundwater Ecology. Academic Press, San Diego, pp. 69-96.

Zuccaro, A., Lahrmann, U., Guldener, U., Langen, G., Pfiffi, S., Biedenkopf, D., Wong, P., Samans, B., Grimm, C., Basiewicz, M., Murat, C., Martin, F., Kogel, K.-H., 2011. Endophytic life strategies decoded by genome and transcriptome analyses of the mutualistic root symbiont Piriformospora indica. PLoS Pathogens 7, e1002290.

Zuccaro, A., Lahrmann, U., Langen, G., 2014. Broad compatibility in fungal root symbioses. Current Opinion in Plant Biology 20, 135-145. 